Deep Sea Research Part II: Topical Studies in Oceanography

August 2017, Volume 142, Pages 167-179

http://dx.doi.org/10.1016/i.dsr2.2017.05.009

http://archimer.ifremer.fr/doc/00385/49614/

(c) 2017 Elsevier Ltd. All rights reserved.

\title{
Fauna and habitat types driven by turbidity currents in the lobe complex of the Congo deep sea fan
}

\author{
Sen Arunima ${ }^{1,{ }^{*}}$, Dennielou Bernard ${ }^{2}$, Tourolle Julie ${ }^{1}$, Arnaubec Aurelien ${ }^{3}$, Rabouille Christophe ${ }^{4}$, \\ Olu Karine ${ }^{1}$
}

${ }^{1}$ IFREMER Centre Bretagne, Laboratoire Environnement Profond, Plouzané, France

${ }^{2}$ IFREMER Centre Bretagne, Unité de Recherches Géosciences Marines, Laboratoire Géodynamique et Enregistrement Sédimentaire, Plouzané, France

3 IFREMER Centre de Méditerranée, Unité Systèmes sous-Marines, La Seyne sur Mer, France

${ }^{4}$ Laboratoire des Sciences du Climat et de l'Environnement, Université Paris-Saclay, Gif sur Yvette, France

${ }^{*}$ Corresponding author : Arunima Sen

\begin{abstract}
:
This study characterizes the habitats and megafaunal community of the Congo distal lobe complex driven by turbidity currents through the use of remotely operated vehicle (ROV) still imagery transects covering distances in the order of kilometers. In this sedimentary, abyssal area about $5000 \mathrm{~m}$ deep and $750 \mathrm{~km}$ offshore from western Africa, large quantities of deposited organic material supplied by the Congo River canyon and channel support aggregations of large sized foraminifers (Bathysiphon sp.) and vesicomyid clams (Christineconcha regab, Abyssogena southwardae) often associated with methane cold seeps, as well as opportunistic deep-sea scavengers. Additionally, bacterial mats, assumed to be formed by large sulfur-oxidizing filamentous bacteria (Beggiatoa type), and black patches of presumably reduced sediment were seen which are, together with sulfur-oxidizing symbiontbearing vesicomyids, indicators of sulfide-rich sediments. Habitat and faunal distribution were analyzed in relation to the microtopography obtained with the ROV multibeam echosounder, at three sites from the entrance of the lobe complex where the channel is still deep, to the main, flatter area of turbidite deposition. Specific characteristics of the system influence animal distributions: both the forams and the vesicomyid clams tended to avoid the channels characterized by high-speed currents, and are therefore preferentially located along channel flanks affected by sliding, and on levees formed by channel overspill. Foram fields are found in flat areas and form large fields, whereas the vesicomyids have a patchy distribution and appear to show a preference for regions of local topographical relief such as slide scars or collapsed blocks of sediments, which likely facilitate sulfide exhumation. The colonization of sulfide rich sediments by vesicomyids is limited, but nonetheless was seen to occur in the main deposition area where they have to cope with very high sedimentation rates (up to $20 \mathrm{~cm} / \mathrm{yr}$ ) and frequent turbidity currents. Other biological adaptations to the local conditions likely determine the presence and survival of animals in the system: large agglutinated forams are known to be adept at quickly colonizing disturbed sediment and capitalizing on abundant but irregular food sources, and vesicomyid clams have a mobile lifestyle that enables them to maintain their population in the ever changing landscape of sulfide-rich sediment outcrops. Turbiditic systems appear to be intermediate between other energy rich habitats sustaining chemosynthesis in the deep sea, being locally less stable
\end{abstract}


in terms of energy supply than cold seeps, limiting the number of cold-seep specialists able to colonize, but constituting a longer lived habitat than food falls. Turbidite fans therefore represent distinct deep sea habitats that contribute to sustaining populations of both chemosynthesis-based and opportunistic taxa in the deep-sea.

\section{Introduction}

The development and constant improvement of multi-beam bathymetry since the seventies has revealed complex morphologies on abyssal plains, showing that the deep seabed is subject to various oceanographic and geologic events, particularly gravity driven processes. For example, the early 
discovery of several deep-sea channels (Dietz, 1953; Dill et al., 1954; Menard, 1955; Smith, 1942) spanning thousands of kilometers, such as the $3800 \mathrm{~km}$ long Northwest Atlantic Mid-Ocean Channel (Chough and Hesse, 1976), has outlined that sediment can be efficiently transferred into the deep sea in massive quantities. Transfer is driven by gravity flows also called turbidity currents, which are essentially underwater sediment avalanches, that can bring massive quantities of sediment and particulate matter down to the deep seafloor in one fell swoop (Meiburg and Kneller, 2010). Turbidity currents, like avalanches, entrain water and sediment as they make their way down the continental slope and can develop their own levees that will confine and favor the transit of river borne terrestrial sediment to the abyss resulting in fan deposits on the seafloor. When a river is linked directly to a submarine canyon, transport of riverine sediment down to the abyss is particularly rapid. The Congo River system is an example of such a system and since the Congo River is the second largest in the world in terms of discharge, (Milliman and Meade, 1983), this means that huge quantities of Congo River sediment and organic matter are funneled and transported by gravity processes into the Congo canyon on the deep seafloor with very little input from the shelf itself (Heezen et al., 1964; Khripounoff et al., 2003; Stetten et al., 2015; Vangriesheim et al., 2009).

Large-scale, organic-rich depositions have been observed to sustain dense benthic communities in turbidite fans, including chemosynthesis based ones, on two occasions before, in the Laurentian Fan and in the Monterey-Ascension Fan (Embley et al., 1990; Mayer et al., 1988; Paull et al., 2010). Geological dive surveys in the channel-mouth lobe area of the Congo deep-sea fan (Savoye and Ondréas, 2000) revealed similar occurrences of large white bivalves resembling vesicomyids and white patches resembling microbial mats (Olu, unpubl. data).

Assessing the extent of this chemosynthetic production as well as understanding the role of organic material-rich turbidite inputs in their development were some of the main objectives of the Congolobe project (Pruski et al., accepted, this issue; Rabouille et al., 2016). The sulfide driving these 
chemosynthetic communities is now hypothesized to be generated anaerobically by microbial sulfate reduction and anaerobic oxidation of methane, itself produced by the diagenesis of the organic matter mainly derived from river deposits (Bessette, 2016; Pastor et al., subm., this issue). The goal of this paper is to describe the distribution of detritic carbon fueled megafaunal benthic communities and chemosynthesis-based habitats inhabiting the channel-mouth lobe of the Congo deep-sea fan. Due to the unique nature of the Congo deep sea fan, the link between marine and terrestrial systems is very short, which has important implications for global carbon budgets and the carbon cycle (Khripounoff et al., 2003).

Large scale ROV (remotely operated vehicle) photographic surveys covering kilometers at three different sites at varying distance along the feeding channel and at various stages of lobe development and various sedimentation rates, were used to visualize lobe complex habitats and fauna. Individuals and aggregations constituting the communities were enumerated with georeferenced mosaics in a Geographic Information System (GIS). We compared the distribution of animals and substrate/habitat types to the fine scale seafloor morphology of the lobes obtained with an ROV mounted multibeam echosounder in order to assess if certain seafloor morphologies could favor the settlement of detrital or chemosynthesis based communities. In addition to the characterization of habitats and communities, another aim of this study was to compare the chemosynthesis based communities of the Congo deepsea fan to a cold seep already described on the continental margin in water $2000 \mathrm{~m}$ shallower ( 3160 m depth, the Regab pockmark), in order to assess how similar the lobe communities are to the cold-seep ones.

\subsection{The study area}

The Congo fan extends $750 \mathrm{~km}$ from the west African shore and spans an area of about 330,000 $\mathrm{km}^{2}$, at a depth of about $5000 \mathrm{~m}$ (Droz et al., 1996; Savoye et al., 2009), The seabed morphology is 
characterized by an intricate network of channel-levees (Droz et al., 2003) among which only one is presently active (Babonneau et al., 2002). The study area is located at the extremity of this active channel-levee, where the channel-levee morphology is less pronounced than further upstream. It is characterized by a stack of lobe-shaped bodies with a diverging pattern, indicative of the loss of confinement of turbidity currents. In total, five partially stacked lobes have been identified, adjacent to each other (Babonneau et al., 2002; Bonnel, 2005; Savoye et al., 2009). Each lobe developed at the termination of distributary channels and the 5 successive lobes have developed and migrated $90 \mathrm{~km}$ south-westward from the channel-levee by successive avulsions of the feeding channel (Dennielou et al., this issue).

Three sites were targeted for this study, along the active distal lobes of the Congo deep-sea fan. Site A is situated across the channel-levee at the entry of the lobe complex, Site F is situated on a more distal position across the same channel-levee at the entrance of the most distal and youngest lobe and Site $C$ is situated at the end of the channel-levee feeding the youngest lobe (Figure 1). Detailed descriptions of each of the sites are available in Rabouille et al. (2016, this issue) and Dennielou et al., (this issue). The morphology and the structure of the lobes suggest that the age of the lobes decreases downstream as one lobe is abandoned when the channel migrates laterally and propagates downstream to build a new lobe (Dennielou et al., this issue). This means that the lobe around Site A is likely the oldest and the lobe around Site C is the youngest of the three sites investigated in this study (Babonneau et al., 2002;

Dennielou et al., this issue; Savoye et al., 2009). However, the study sites are localized along the active feeding channel and adjacent sedimentary levees that have recorded active depositional and erosional sedimentary processes throughout the last century (Rabouille et al., 2016, this issue). Sites A and F are bisected by the active channel feeding the lobe complex. At Site A, the channel is about $45 \mathrm{~m}$ deep and about $1400 \mathrm{~m}$ wide and at Site $\mathrm{F}$, the channel is of approximately the same depth, but much wider (approximately $2.5 \mathrm{~km}$ ). A smaller, less pronounced and less active channel also runs through the 
northern part of Site A, linking it to lobe 3 . Though the main active channel is visible at Site $C$, it is much shallower (only 4 - $11 \mathrm{~m}$ deep) and less pronounced than at the other two study sites. In addition to the study sites located along the active feeding channel, information from video surveys in lobes partially or totally disconnected from the present channel (sites E and D) were included in the discussion (Figure 1).

\section{Methods and Materials}

Still imagery and multibeam data were collected during the Congolobe cruise in December, 2011 aboard the R/V Pourquoi Pas? using the ROV Victor 6000 (Rabouille, 2011). Previous exploratory dives were conducted during the West African Cold Seeps (WACS) cruise in February, 2011 (Olu, 2011) and during the ZAIROV cruise in December, 2000 (Savoye and Ondréas, 2000), that helped define the Congolobe dive strategy. Detailed ROV photo surveys conducted during the Congolobe cruise were used to map communities and habitats for this study, and additionally, a few remarkable chemosynthesis-based habitats sampled during the WACS and Congolobe cruises but not seen in the Congolobe cruise photo surveys were taken into account while discussing patterns of distribution.

At each of the three sites, detailed bathymetry and high-resolution images were collected in order to visualize the seafloor morphology and benthic fauna. A Reson Seabat 7125 echosounder mounted on the ROV was used to obtain bathymetric data. An altitude of $60 \mathrm{~m}$ was maintained during acquisition of bathymetry data, which provided resolution up to $1-2 \mathrm{~m}$ and accuracy up to $0.1 \mathrm{~m}$. Additionally, at the three study sites, bathymetric surveys were conducted at an altitude of $6 \mathrm{~m}$ providing resolution up to $0.2 \mathrm{~m}$. The total length of seafloor surveyed during the high resolution, low altitude surveys was $21 \mathrm{~km}$ at Site $A, 17 \mathrm{~km}$ at Site $\mathrm{F}$ and $30 \mathrm{~km}$ at Site C. Details on the bathymetry mosaics are presented in this issue, (Rabouille et al., 2016). The bathymetry data was processed in CARAIBES, a software developed at Ifremer, France (Simeoni et al., 2007) and georeferenced bathymetric maps were created for each study site. 
The high sensitivity, digital still OTUS camera featuring a CCD THOMSON MPP greyscale sensor, with a resolution of 1 megapixel and 14 bits per pixel (Simeoni et al., 2007), was used to conduct image surveys of the three study sites. Photographic surveys were designed based on the lobe complex morphology (crossing the channel and on adjacent levees, south and north) and were conducted simultaneously with the high resolution, low altitude bathymetry data acquisition. The camera was mounted vertically on the ROV, enabling a downward facing position. Altitude, usually maintained at $6 \mathrm{~m}$ (lowered on selected sites to allow for video observations) during the surveys, and slow speeds, of about 0.5 knots/hour, ensured overlap between successive images. Photographic surveys were conducted in a lawn mower fashion, except in the case of Site F, where only single or dual transects were made along and across the channel running through the middle of the site. Additional information about the extent of the area of occurrence of chemosynthesis-based communities were obtained from video surveys conducted at an altitude of $3 \mathrm{~m}$ above the seafloor from the WACS cruise. Other video surveys were used to make observations at site $\mathrm{D}$, (located about $30 \mathrm{~km}$ downstream of site $\mathrm{C}$ along the main depositional axis but out of the youngest lobe), site B (located $\sim 20 \mathrm{~km}$ north-west of site $A$ in lobe 3 and $10 \mathrm{~km}$ north of the active feeding channel), and site E (located along a previous channel, now inactive, Figure 1).

The raw TIFF images outputted by the OTUS camera were processed in Matisse v3, a software developed at Ifremer (Arnaubec et al., 2015). This software was also used to stitch the images together in order to create seamless, georeferenced mosaics of the three sites. The pixel size for the photomosaics is about $1 \mathrm{~cm}$, which allows for features of $10 \mathrm{~cm}$ and above to be resolved. An example of a mosaic zoomed in to the point where both animals and seafloor characteristics is visible is shown in Figure 2, along with an image used to construct that part of the mosaic. The mosaics were overlain on the bathymetry maps in ArcGIS 10.2 in order to visualize both the seafloor and the benthic communities. Megafauna, bacterial mats and patches of reduced sediment were marked or outlined within ArcMap 10.2. The following categories were seen and outlined: reduced black sediment (very dark black in color, 
distinct from surrounding sediment), mixed black and white sediment (likely consisting of both bacterial mats and reduced, black sediment), distinct white bacterial mats, patchy black sediment (lighter black than reduced black sediment patches and less distinct from surrounding sediment), patchy white sediment (similar to patchy black sediment, this category includes areas where a number of indistinct white patches were seen), dense vesicomyid clam patches, dense clam shell fields and large sized foraminifers identified as belonging to the genus Bathysiphon (close to B. filiformis but likely a new species; A. Gooday, pers.com.) from samples. Examples of the different categories are shown in Figure 3. Additionally, individuals of the following animal groups were marked as points: anemones, fish (most likely a number of zoarcid species, due to their anguilliform shape), shrimp, moving individual clams (outside clam patches), Munidopsis squat lobsters, and holothurians. Animal collections were made during the Congolobe cruise in order to identify the species present. However, such sampling was focused on vesicomyid clusters; therefore, animals present outside such clusters could not be identified to the species level and for this reason, general taxonomic groups such as fish, anemones and holothurians are used in this study. A few individuals of squat lobsters were collected from the lobe sites and identified as being Munidopsis crassa (E. MacPherson, pers. comm.); however since this sampling was not comprehensive, the presence of more than one Munidopsis species cannot be ruled out and therefore the squat lobsters seen in the photomosaics for this study are not referred to by a species name. The collections revealed the presence of two different vesicomyid species: Christineconcha regab (Krylova and von Cosel, 2011; von Cosel and Olu, 2009) and Abyssogena southwardae (Krylova and Sahling, 2010; Teixeira et al., 2013). The proportions of the two species differed between collections taken at the three sites (Decker et al., subm., this issue) but the low number of collections makes it difficult to come to any definitive conclusions about the relative abundances of these two species in the Congo deep lobe complex. Furthermore, the two species are not possible to tell apart in images. Therefore, patches and clusters of vesicomyids were digitized as one, single category, as opposed to the 
two different species being digitized separately. The distribution, areal cover and densities of different faunal groups and sediment types were examined within each site and comparisons were made across the three sites and discussed according to environmental parameters (position of each site within the lobe area, sedimentation rates, seafloor morphology, etc.). Comparisons were also made with the cold seep community found at the shallower Regab pockmark (3200 m depth), located $5 \mathrm{~km}$ north of the active Congo turbiditic channel, $450 \mathrm{~km}$ upstream of the lobe complex area.

\section{Results}

\subsection{Distribution of chemosynthesis based communities and habitats}

\subsubsection{Vesicomyid clam clusters}

Vesicomyids were seen in dense clusters in all three study sites. The image quality was not sufficient for robust quantification of exact densities within the clusters, but the average density of vesicomyids from a few pictures where individuals were clearly visible was 416 individuals per square meter. The sizes of the patches tended to be rather small, ranging from $15.45 \mathrm{~cm}^{2}\left(0.00145 \mathrm{~m}^{2}\right)$ to $23.58 \mathrm{~m}^{2}$ and on average covered $0.19 \mathrm{~m}^{2}$. The total area covered by vesicomyid patches at three study sites are as follows: $65 \mathrm{~m}^{2}$ of $138290 \mathrm{~m}^{2}$ surveyed $(0.05 \%, n=231)$ at Site $A, 5.5 \mathrm{~m}^{2}$ of $99415 \mathrm{~m}^{2}(0.006 \%, \mathrm{n}=85)$ at Site $F$ and 28 $\mathrm{m}^{2}$ of $190190 \mathrm{~m}^{2}(0.015 \%, \mathrm{n}=119)$ at Site $\mathrm{C}($ Table 1$)$.

At Sites $A$ and $F$, where the active depository channel is very pronounced, the vesicomyids displayed a tendency for avoiding the channel itself (with the exception of one small cluster of about 20 visible individuals at Site A within the channel, Figures 4-5). Additionally, at Site A, vesicomyids tended to be absent within the less active, older channel, northward of the main active channel as well. At Site C, where the channel is much shallower and less pronounced, vesicomyids did not tend to avoid the channel and in fact, inhabited it in dense clusters, although not very frequently (Figure 6). 
Despite their absence from within the depository channel at Sites $A$ and $F$, vesicomyids were present on either side (along the flanks or on the levees) of the active channel, in numerous dense patches. At Site A, the southern flank of the main channel was particularly densely colonized by vesicomyid clams and one area, of about $100 \mathrm{~m} \times 100 \mathrm{~m}$ was covered in dense assemblages of both dead and living vesicomyid shells. This area is referred to as 'Vesico Bay' (Figure 4). It corresponds to an arcuate head wall that is interpreted as a slide scar (Dennielou et al., this issue; Rabouille et al., 2016). The base of the wall shows a few blocks of sediments that constitute the remains of the collapsed sediment, suggesting that most of it was transported further down, into the channel. Similar scars visible along the southern side of the channel reveal frequent instances of sliding. In contrast to vesicomyid clam clusters in the rest of the lobe complex, Vesico Bay hosted large clam aggregations very close to each other, as well as a noticeable amount of empty shells that were quite rare at the other sites (Fig 4).

Overall, vesicomyid clam clusters appeared to coincide with areas exhibiting some rugosity and relief related to the collapse of blocks of sediment. The association between vesicomyids and relief was not always evident in the mosaics because the downward facing position of the OTUS camera obscures small-scale relief patterns. However, the bathymetry and slope maps revealed that vesicomyids were often located on gradients (slopes, including areas of instabilities), though these gradients tended to be small, and did not exceed 50 degrees (at the resolution of the bathymetry map). Examples are shown in Figure 7 (also see note in Supplementary Figure 2).

The presence of vesicomyid clams appeared to be correlated with the presence of discrete patches of reduced, black sediment. Most vesicomyid patches were found to be situated in areas of reduced black sediment. However, not all vesicomyid patches appeared to be within areas of black sediment and not all areas of black sediment were occupied by vesicomyid clams. At Site A, 186 patches of black, reduced sediment were seen and 169 of them were occupied by vesicomyid patches (90.8\%). In total, 231 aggregations of clams were seen at Site $A$ and of these, 172 (74.5\%) were on patches of reduced black 
sediment. At Site $\mathrm{F}$, only $21 \%$ of the black patches were occupied by vesicomyid clams; and $56.5 \%$ of the vesicomyid aggregations were found to be on black reduced sediment. Site $\mathrm{C}$ hosted the largest number of patches of reduced black sediment (700), but only less than $9 \%$ were colonized by vesicomyids. $60.5 \%$ of these vesicomyid clusters were located on patches of black, reduced sediment (Table 1).

Most solitary individuals of clams that were seen to be outside the dense clam clusters were in the very near vicinity of the dense aggregations. A few individuals were seen some distance away from the nearest digitized clam clusters, but it is possible that dense aggregations were close by and simply not covered by our photographic surveys. The trails of individual clams could clearly be seen in the sediment and they often covered distances in the tens of meters, frequently connecting several clam patches (Supplementary Figure 1).

\subsubsection{Dead vesicomyid (shell) clusters}

Clam shells were seen at all the three sites, generally near or around aggregations of live individuals. However, large, dense fields of clam shells were absent. At Site F and particularly at Site C, large tracts of area display a textured pattern to the sediment that could possibly result from sediment layers depositing over clam shells. At site A, empty shells were abundant around the living aggregations in Vesico Bay.

\subsubsection{Reduced black sediment}

Discrete patches of black, reduced sediment appeared to follow a similar pattern of distribution to the vesicomyid clams. Similar to the clams, they tended to occur on the flanks and levees at sites A and F, and in general were seen in areas displaying blocky bottom morphology. They did not occur in the deepest and smoothest parts of the channels. 
Areas with multiple, faint patches of black, reduced sediment (patchy black sediment) were not as visible at Site A compared to the other two sites. At Site F, these areas were often found in the areas adjacent to and surrounding discrete black patches. At Site $C$, they were much more ubiquitous, but often extended from areas where discrete black sediment patches were seen. Similar to vesicomyids and discrete black patches, patchy black sediment was not seen in the deepest and smoothest parts of the channels except at Site $\mathrm{C}$ where the channel consists of more of an area of sediment spreading than a channel in the true sense.

\subsubsection{Bacterial mats}

Bacterial mats and mixed black and white patches were almost absent from Site A. They were not seen in the OTUS photomosaics of this site at all, but a few were observed in the $3 \mathrm{~m}$ altitude video surveys taken along the eastern part of the southern flank of the channel in 'Vesico Bay'. Bacterial mats were abundant at Site F; however, only two instances of mixed black and white patches were seen at this site. Both bacterial mats and mixed black and white patches were abundant at Site C (Figures 4-6). In general, across the sites where they are present, both of these types of sediment/habitats were close to areas of reduced black sediment. However, at Site $F$, there are a number of white patches that are located on the eastern portion of the mosaic area that are quite distinct and some distance away from black patches of reduced sediment (minimum distance $178 \mathrm{~m}$ ). These patches tended to be on some of the highest bathymetric points within the mosaic site. At site $C$, the mixed black sediment and white patches were more abundant to the south of the channel in an area with a blocky sea bottom morphology. They seemed to occur on top of partly buried blocks.

Vesicomyids were never seen on mixed patches and with the exception of one, large bacterial mat at

Site $C$, were also not seen on white, bacterial mats. However, it should be noted that patches containing black sediment, white bacterial mats and vesicomyids all together in one patch, have been seen in video 
transects and at site $F$, and a few different bacterial mats were seen to be colonized by vesicomyid clams, despite not being present within the OTUS photomosaics.

\subsection{Distribution of heterotrophic fauna}

\subsubsection{Foraminifers}

The foraminifer of the genus Bathysiphon was very abundant at Sites A and F, even forming fields of individuals, covering hundreds of square meters, but was completely absent from Site C. Densities were difficult to enumerate with the resolution of the OTUS camera, but an examination of a few good images indicates that their densities can reach about 10 individuals per square meter, although, are often lower. Similar to the vesicomyids, the forams tended to avoid the channel that runs through both sites $\mathrm{A}$ and $\mathrm{F}$. However, they did not fully overlap with vesicomyid clams in their distribution. While the vesicomyids were most concentrated in areas adjacent to the channels, foram fields were also found further away from the channels in areas with smoother morphologies. Even in instances where forams and vesicomyids were in close proximity to each other, they did not overlap and patches of clams were quite distinct from where the forams were present and forams did not occur amidst clam aggregations (Figures 4-6). Similarly, forams were not found within any of the patches of reduced, black sediment and even appeared to avoid areas of patchy black sediment as well. Despite the lack of overlap, forams were often seen in close proximity to vesicomyid aggregations (Supplementary Figure 2). Unlike the vesicomyids, the forams were present in very flat areas. The maximum value of slope gradient associated with forams was about 47 degrees, however, more commonly, forams were associated with areas sloping at an angle of less than 20 degrees.

\subsubsection{Vagile taxa}

Fish were seen at all three sites and appeared to be evenly distributed at each site (Figures 8-10).

Shrimp were present at all sites and appeared to be evenly distributed as well. The densities of fish and 
shrimp were very similar across all the three study sites. At each of the 3 sites, 0.001 individuals of fish $\mathrm{m}^{-1}$ were seen, and between 0.0003 to 0.0009 shrimp $\mathrm{m}^{-1}$ were seen across the three sites. Anemones were quite rare overall. They were completely absent from Site C, but 15 individuals were seen at Site A and seven, at Site F. In both cases, they were associated with or very near dense vesicomyid patches or shells. Munidopsis squat lobsters were even rarer: seven individuals were seen at A near or within vesicomyid patches, 2 at $\mathrm{F}$ and only a single individual was seen at $\mathrm{C}$ far removed from visible vesicomyid clam patches but near patches of black, reduced sediment or within a foram field at site F. Only two individuals of holothurians were seen, at Site F, and they were not associated with vesicomyid patches, or any reduced habitat nor foram field. However, one holothurian was seen within a foram field and close up videos revealed the presence of translucent holothurians within clam patches (Pruski et al., accepted, this issue).

Figure 11 summarizes the distribution of animals in relation to topographical features and habitat types in the lobe complex.

\section{Discussion}

Benthic communities often display low biomass because of the lack of a local energy source and the distance separating them from places of primary production (Rex, 1981). However, when the limiting condition of a proximate energy source is satisfied on the seafloor, extremely high biomass communities can develop. This can occur through chemoautotrophy via the use of reduced compounds (Fisher et al., 2007; Sibuet and Roy, 2002; Van Dover, 2000), or through influxes of large amounts of organic matter to the seafloor, in the form of deposits of animal and plant matter (Bernardino et al., 2010; Smith and Baco, 2003). In the first case, they can persist for time periods longer than most animal lifespans by chemical energy supplied through a well-stocked reservoir until fluid pathways become clogged by mineral precipitation (Cordes et al., 2005). The second category (food falls) are colonized by 
opportunistic background fauna and can transition to chemosynthesis based communities over time, but are shorter lived as exist for only as long as the physical remains of the organism or structure around which they have developed persist.

\subsection{Turbidites sustain several community types in the Congo distal lobe complex}

The Congo turbidite system deposits large quantities of terrestrial organic matter on the deep seafloor (Stetten et al., 2015), which sustains both heterotrophic and chemosynthesis based animal communities. This is conceptually similar to large food falls, however, continued turbidity currents (every 6-17 years, (Dennielou et al., subm., this issue, and every two years in the canyon based on cable break data, Heezen et al., 1964), make this system much more long lived (ca. 4000 years old Picot, 2015; Savoye et al., 2009) than the average food fall. However, the system is also affected by a high degree of physical perturbation with high energy turbiditic currents and massive sediment deposits (mean sedimentation rate estimated up to $20 \mathrm{~cm} / \mathrm{yr}$, but can be much higher Rabouille et al., 2016) which can limit faunal settlement and persistence.

\subsubsection{Direct use of turbiditic inputs: the Bathysiphon population}

Large, aggluninated foraminifers of the genus Bathysiphon were seen to form large aggregations, covering hundreds of meters. The forams displayed no overlap with areas indicative of reducing environments such as patches of black, sediment, vesicomyid aggregations, or microbial mats. This indicates that they do not rely on chemoautotrophy, but feed directly on organic matter. The cytoplasm of sampled individuals was found to very dark (A. Gooday, pers. com.), which is indicative of detrital particles and further evidence in support of the idea that these animals are conventionally heterotrophic. It is not possible to definitively distinguish between sediment or water currents as the major food source. However, the forams were found in areas of smooth morphology, as opposed to slopes and local highs. This suggests that they are surface feeders, because water column feeders tend 
to prefer elevated locations due to the disruptive effect such locations have on prevailing currents, which can result in higher food fluxes (Duineveld et al., 2007; Genin et al., 1986). Indeed, the curvature of the lower portion of the lobe forams' tubes has been hypothesized to promote surface feeding in the closely related species B. filiformis (Gooday et al., 1992).

Large, agglutinated forams are often found along the marginal zones of ocean basins and particularly, in areas of high organic input, including canyons subjected to turbidity currents (Duros et al., 2011; Hess et al., 2005; Hess and Jorissen, 2009; Koho et al., 2008). The unevenly spaced growth bands on their tubes indicate long term but irregular patterns of food availability, as opposed to distinct annual cycles (Gooday et al., 1992). Furthermore, benthic forams are known to rapidly colonize highly disturbed areas (Alve, 1999). Therefore, it is possible that the Congo lobe complex represents a habitat that the resident forams are very well adapted to, i.e., a region with high organic material inputs (turbidites) that are spaced apart unevenly over time.

However, particularly frequent or large turbidity currents that could lead to deep burial are likely to be detrimental to the lobe forams. They were absent from the channels running through the study sites , which are subjected to coarse, dense and high velocity parts of the turbidity currents (e.g. Mulder, 2011), in comparison to lower energy overflows on the adjacent levees where they were abundant (Rabouille et al., 2009). Furthermore, the forams were completely absent from Site $C$ and since this site is downstream of the other two study sites, and since forams were seen ever further downstream, at Site $D$ (see location in Figure 1), dispersal barriers are unlikely to be responsible. Site $C$ is where the channel is very shallow (4-11 m), and is where turbidity currents lose confinement, spread out over the seabed and eventually die out (Dennielou et al., this issue). A shallow channel means that the entire Site C, including the levees, probably undergoes hydro-sedimentary stress (both deep burial and erosion) similar to the channels at sites A and F, making the site as a whole, unfavorable for the forams. Sedimentation rates at Site $\mathrm{C}\left(22 \mathrm{~cm} \mathrm{yr}^{-1}\right)$ are considerably higher than at the other two sites as well (2.5 
and $1 \mathrm{~cm} \mathrm{yr}^{-1}$ in the channels near Site $\mathrm{F}$ and at Site $\mathrm{A}$ respectively, and $0.7 \mathrm{~cm} \mathrm{yr}^{-1}$ on the levee near Site F, Rabouille et al., 2016). It should be noted that these estimates of sedimentation rates are not continuous rates but are the result of several, likely irregular, turbiditic events. These rates are therefore proxies for understanding the extent to which animals can get buried by the turbidites that can result in sedimentation rates even higher than the already very high estimations.

In short, the large foram fields are assumed to be sustained by the direct use of turbiditic inputs. They are likely capable of coping with periodic burial events to a certain extent, but most likely cannot tolerate deep or complete burial and dislocation. It is highly possible that forams mainly utilize material at the sediment surface, which could explain why they appear to prefer smooth, flat areas as opposed to locally elevated areas that could potentially be exposed to high fluxes of food passing by in the water column (Figure 11). They likely represent a group of opportunistic taxa that is adapted for and capable of coping with irregularly timed, but yet fairly frequent turbidity current driven disturbances.

\subsubsection{Long term use of turbiditic inputs: the chemosynthesis-based community}

The other highly abundant faunal group is the vesicomyid clams. Members of the Pliocardiinae subfamily, to which all large-size vesicomyid clams belong, contain sulfur oxidizing bacterial symbionts (Krylova and Sahling, 2010). Thiotrophic symbionts were identified in the gills of both species sampled in the lobes (Decker, unpubl. data), consistent with stable isotopic signatures and fatty acid contents pointing towards a sulfide based chemoautotrophic lifestyle (Pruski et al., accepted, this issue).

In accordance with these findings, the lobe vesicomyids were often seen on black sediment and often, these coincided with blocky, raised areas, or along slopes and instabilities created by mass wasting assumed to exhume sulfide. The major (and only) large clam field was located at the base of a large slide scar ('Vesico Bay') at site A, and many other aggregations were found in sliding areas along the southern channel wall at this site as well. The association between vesicomyid clams and blocky areas as well as erosion resulting from slumping events has also been hypothesized to create methane and sulfide rich 
environments to support chemosynthesis-based communities in other turbidite fan systems (Mayer et al., 1988; Paull et al., 2010).

High speed currents likely limit clam colonization, because they can physically displace the animals, or because they prevent the deposition and decomposition of organic material and the subsequent production of sulfide. Upstream in the channel, current speeds of up to $121 \mathrm{~cm} / \mathrm{s}^{-1}$ were measured in the channel at $4000 \mathrm{~m}$ depth (Khripounoff et al. 2003). Although currents likely decrease at the lobe entrance (Vangriesheim et al., 2009), high speed currents are still likely to be a feature of channels, where they occur. Indeed, at sites A and F, where a clearly defined channel is present, clams were absent from within the channel itself (with the exception of one aggregation at site A). At site $C$, the channel is wider, and currents are slower, which, combined with higher sedimentation rates, allows for the establishment of more sulfide-rich habitats suitable for clam colonization, and, in fact, patches of black, reduced sediment, were much more abundant at site C compared to the other two study sites. However, occupancy of black patches by vesicomyids was very low at site C (only $9 \%$ compared to $21 \%$ at site $\mathrm{F}$ and $91 \%$ at site $\mathrm{A}$ ). Sedimentation rates at site $\mathrm{C}$ are many times higher than the sedimentation rates at the other sites, which suggests that similar to the forams, very high sedimentation rates and frequent turbidity currents may limit colonization by clams, even when suitable habitat is available. Black sediment is not necessarily the only locations suitable for clam colonization, but the absence of clams from such locations indicates that potentially good clam habitats are left unoccupied. Juvenile vesicomyids can colonize bacterial mats (Guillon et al. 2017; Olu et al., accepted this issue), and over time, they can progressively modify geochemical gradients by deepening the sulfide production zone in the sediment through bio-irrigation (Fischer et al., 2012; Taillefert et al., subm., this issue) and, by this process, outcompete sulfide oxidizing bacteria in microbial mats that require sulfide to be present shallow in the sediment in order to also have access to oxygen from the overlying seawater. Growth rates of the lobe vesicomyids are not known, but were estimated to be about $8 \mathrm{~mm} / \mathrm{yr}$ for $C$. regab in 
the Regab pockmark (Decker, 2011; Guillon et al., 2017); which is in the upper range of vesicomyid growth rates (Barry et al., 2007). Using this growth rate, lobe vesicomyids would take 7.5 years to reach the average adult size of $60 \mathrm{~mm}$. Although we may assume higher growth rates in the lobe area as an adaptation of higher perturbation, the high turbidite event frequency (every 6 to 17 yrs according to Dennielou et al., (this issue)) could result in physical dislocation and disorientation of the clams before they reach larger sizes as well as interruptions to the habitat modification process carried out by microbes and conspecifics that could be important for further recruitment.

However, the vesicomyid clams are probably not as susceptible to burial events and can deal with erosional stress better than the forams, since they nonetheless colonize the area of main turbiditic deposition. Indeed, contrary to the forams they are mobile (many tracks were seen) and can reposition themselves after a catastrophic event and even prevent complete burial either by moving upwards in the sediment with a muscular foot, or by extending their siphons to the water column (Krylova \& Cosel 2011).

In summary, a combination of access to sulfide and tolerable levels of turbidite activity likely determines the distribution of vesicomyid clams within the lobe complex (Figure 11). 'Vesico Bay', located on the debris of a slide along the channel wall at the entrance of the lobe complex, contains many clam clusters, shells and microbial mats, making it the most densely populated region by vesicomyid clams and likely the most stable, in the lobe complex. It is possible that this region experiences an optimal balance between the driving factors of highdeposition/erosion by turbidity currents and limited current speed, supplying both enough organic material as well as enough stability for establishing a clam field as opposed to the very patchy distribution seen in the rest of the complex.

\subsubsection{The Congo turbiditic lobe complex as a long term habitat for opportunistic vagile fauna}


A number of vagile faunal groups were seen in the lobe complex, such as, Munidopsis squat lobsters, fish, shrimp, and more rarely, holothurians. These animal groups did not appear to display a preference for either the forams or the clams; with the exception of anemones, which appeared to associate with vesicomyid clams, probably because of hard substrates (shells) or high primary productivity within the vesicomyid community.

Zoarcids were the most abundant among the fish, and this group is known to capitalize on high biomass or high primary production areas such as food falls or vents and seeps (Bailey and Priede, 2002; Biscoito et al., 2002; Janßen et al., 2000; Witte, 1999). They have been found to feed on microbial mats or associated consumers at seeps but may have a wide range of nutritional sources including non-seep detrital material (Decker et al., 2012; Olu et al., 2009) The zoarcid fish from the lobe complex were not sampled, but Munidopsis squat lobsters and holothurians in the lobe complex were different from the species found at the Regab cold seep site. Therefore, none of the vagile fauna seen in the lobe complex appear to be seep specialists, but rather, are opportunistic colonists. Higgs et al. (2014) found and studied four carcasses on the seafloor, within an area of just $1.48 \mathrm{~km}^{2}$, on the continental margin about $70 \mathrm{~km}$ south east of the Congo distal lobe complex (but at only $1200 \mathrm{~m}$ depth). It is extremely rare to find natural vertebrate carcasses on the seafloor (only 9 have been discovered so far in five decades of deep-sea photography), and the authors suggest that this region of the world's oceans supports a particularly high frequency of large food falls to the seafloor, which could mean that large animal carcasses are a major food source in the Gulf of Guinea. The Congo deep sea fan could also contribute (albeit more permanently and persistently) to sustaining opportunistic fauna in this area, rather than seep specialists, at least for the non-symbiotrophic, megafauna.

Food falls tend to follow a series of successional stages, with, the 'mobile-scavenging stage', where scavenging animals and fish dominate, the 'enrichment-opportunist stage', in which sediments near the skeleton are rich in organic matter and densely colonized by deposit feeders, and the 'sulfofilic stage', 
characterized by chemosysnthesis based animals (Smith and Baco, 2003). The last two stages are either limited in scope, or absent from non-cetacean based food falls (Higgs et al., 2014). The presence of fish, scavengers, (e.g. galatheids) deposit feeders (e.g. holothuroids, shrimps, foraminiferans) and chemosynthetic animals means that the Congo lobe complex hosts all three of the major successional stages of marine food falls simultaneously. The scavenging aspect of the first stage is limited by the absence of large animal remains, but dead animals (e.g. vesicomyids) buried by turbidites may be a potential food for scavengers. Due to the spatially and temporally heterogeneous settlement of turbiditic organic matter, multiple temporal phases of food falls are visible at the scale of the lobe complex as a whole. Therefore, one could consider the Congo lobe complex as a mosaic of habitats that resembles the various successional stages of marine food falls and the spatial proximity of such communities that are normally temporally separated from each other could lead to interactions that probably do not occur at regular food falls. Therefore, the Congo turbidite system sustains both opportunistic heterotrophic fauna and chemosynthesis based animals on the deep-sea floor, through massive organic matter inputs persistent over a large area and over much longer time scales than regular food falls.

\subsection{Comparison to the Regab cold seep site and to other turbidite fan systems: dominance of} vesicomyids

The Regab pockmark, belonging to the same Congo turbidite system, is located in water 2000 meters shallower, $450 \mathrm{~km}$ upstream, and $8 \mathrm{~km}$ north of the turbiditic channel. It is linked to a deep buried paleo-channel which is hypothesized to act as a reservoir for seeping fluids (Gay et al., 2003; Ondréas et al., 2005), which sustains dense populations of vesicomyid clams and two other chemosynthesis based animals, vestimentiferan tubeworms, and bathymodioline mussels. (Marcon et al., 2014; Olu-Le Roy et al., 2007; Ondréas et al., 2005). Additionally, both seep specialist and opportunistic vagile taxa also make up the Regab community (Olu et al., 2009). 
Despite the proximity of Regab to the Congo turbidite fan, the latter only hosts one type of seep specialists, the vesicomyid clams, including the dominant species at Regab. The absence of mussels and vestimentiferans in the lobes, which are very abundant on the pockmark, could be explained by the absence of carbonate concretions within the lobe complex, which are necessary for vestimentiferan settlement (Bright and Lallier, 2010; Southward et al., 2005) and the preferred substrate of bathymodioline mussels (Bergquist et al., 2003; Cordes et al., 2005; Olu-Le Roy et al., 2007). The lack of carbonates could be the result of water depth $(5000 \mathrm{~m})$, which places the lobe complex in the zone between the lysocline (4700 m - 5200 m, Berger, 1968) and the carbonate compensation depth (at least $5600 \mathrm{~m}$, (Thunell, 1982).

Alternatively, fluid emission regimes could account for the differences. At Regab, methane hydrate dissociation is assumed to sustain fluid outflows, which leads to stable and constant leakage of reduced compounds (Charlou et al., 2004; Marcon et al., 2014). However, in the lobe complex, production and availability of sulfide is likely controlled by post-depositional sedimentological processes such as focused dewatering during sediment compaction and exhumation of deep sulfides after mass wasting (Dennielou et al. this issue), leading to a patchy distribution of sulfide-rich sediment. Patchiness may also be promoted by factors inhibiting the availability of sulfide such as burial, erosion or high-velocity turbidity currents. Forams were often seen very close to vesicomyid aggregations (Supplementary Figure 2), which suggests that very little lateral diffusion of sulfide takes place within the sediment, supporting the hypothesis of sulfide rich sediment being very patchy and likely present in very limited amounts locally. This suggests that sulfide reserves in the Congo turbidite system may be locally exhausted rather rapidly. Subsequently, chemosynthesis based animals would require a mobile lifestyle and some degree of flexibility regarding fluid fluxes to survive in the Congo turbidite system. Vesicomyids have been observed to display both of these characteristics at Regab: aggregations were seen to reposition themselves over the course of a ten year study, and they were seen to cope with 
different fluid flow regimes, (high or low intensity), as well as transient fluxes (Marcon et al., 2014). On the other hand, the area covered by bathymodiolid beds and siboglinid tubeworm clusters did not appear to increase or decrease nor move over the same time period, and these animals were seen to be more specific in their habitat, colonizing only areas of stable and high intensity flux. Additionally, the ability of vesicomyids to move regularly could also be advantageous for coping with burial during turbitic events. Similar observations were also made among clam aggregations in the Monterey-Ascension turbidite fan system as well: the authors noted an abundance of clam trails in the sediment, which they considered evidence for a highly mobile lifestyle (Embley et al., 1990).

Vesicomyids are moreover able to enhance sulfide production by bio-irrigation and bioturbation of the sediment, facilitating sulfate penetration (Wallmann et al.1997; Fischer et al. 2012). By deepening the sulfide production zone (SMTZ) to the depth where their feet pump up sulfide, they are able to maintain conditions to sustain their growth. Evidence for this hypothesis was found in the lobe area, where the depth of highest sulfide concentration was found to be related to vesicomyid shell length (Decker et al., subm., this issue). This behavior would be particularly advantageous in places with limited methane and sulfide resources, such as the Congo lobe complex.

A number of similarities exist between the Congo lobe complex and the other two densely populated turbidite fans that have been studied, the Laurentian Fan and the Monterey-Ascension Fan (Embley et al., 1990; Mayer et al., 1988). In all three cases, the dominant animals are vesicomyid clams adapted to the patchy distribution of sulfide-rich sediments, which often coincide with contours, crests, elevations, and instabilities. Siboglinids, as well as carbonates, were observed (rarely) along the Monterey canyon flanks (Paull et al.2010), however, this area experiences less frequent turbidity currents (one per century) in comparison to the Congo canyon ( 60 per century), facilitating the settlement of a more diverse cold seep like community. The similarities among studied turbidite systems, both in terms of dominant community members and their distributional patterns suggest that turbidite systems share 
certain characteristics with other high energy habitats on the seafloor such as food falls or seeps, but are nonetheless more similar to each other and constitute a specific deep sea habitat. Animals that thrive in these systems must be able to tolerate catastrophic turbidity currents, including the ability to rapidly colonize after such events, and chemosynthesis based animals need to be able to move from one sulfide reserve in the sediment to another, therefore limiting the potential candidates to vesicomyids.

\section{Conclusion}

The Congo lobe complex shares certain features with energy rich, deep seafloor habitats such as cold seeps and food falls. However, the similarities are very limited in scope (e.g., only one seep symbiontbearing taxon was seen in the lobe complex), or differ in scale (temporally distinct successional stages of food falls occur simultaneously in the lobe complex). This is likely due to high energy and frequent turbidity currents being major structuring components of the system. Figure 11 summarizes the distribution of animals in relation with the specific characteristics of the Congo fan complex. For example, high velocity currents prevent colonization of foraminiferans and vesicomyid clams in the narrow parts of the channel and instead, they colonize the canyon flanks and levees. Downstream, where the channel becomes wider and shallower, vesicomyids colonize both the channel and the levees, but foraminiferans are not present, likely because of extremely high sedimentation rates. Moreover, variability in post-depositional sedimentological processes leads to limited, patchy and transient sulfide exhumation, controlling the distribution of chemosynthesis based habitats, which requires animals dependent on such habitats to have a mobile lifestyle. This suggests that turbidite fans constitute a specific habitat type on the deep seafloor that host benthic communities adapted for capitalizing on abundant resources, while tolerating erosional and burial stress. However, these systems host both opportunistic and chemosynthesis-based fauna even in very deep water, and can act as more permanent stepping stones than pelagic food falls for deep sea fauna adapted to fragmented and unstable habitats. 
Acknowledgements

The authors would like to thank the captain and crews of the R/V Pourquoi Pas? and Victor 6000 for their assistance in day to day operations and data collection at sea during the Congolobe cruise (Chief scientist C. Rabouille). We are also very grateful to Laurence Droz, Marie Picot and Morgane Le Saout for real-time treatment of ROV bathymetry and, help from Christophe Bayle, which defined the tracks for the OTUS camera surveys. Carole Decker is acknowledged for her help on board. We are indebted to Andy Gooday, for identifying foram samples and discussing the biology of forams with us. We would also like to thank the Congolobe working group, for fruitful discussions. Funding for this study was provided by the French National Agency for Research (ANR) Congolobe ANR Blanc SIMI5-6, no.11BS56030.

Arunima Sen's post-doc was funded by IFREMER and Institut Carnot Edrome (Agreement Ifremer-Carnot N¹1CARN018-01 and N¹3CARN018-01).

\section{References}

Alve, E., 1999. Colonization of new habitats by benthic foraminifera: a review. Earth-Sci. Rev. 46, 167185. doi:10.1016/S0012-8252(99)00016-1

Arnaubec, A., Opderbecke, J., Allais, A.G., Brignone, L., 2015. Optical mapping with the ARIANE HROV at IFREMER: The MATISSE processing tool, in: OCEANS 2015 - Genova. Presented at the OCEANS 2015 Genova, pp. 1-6. doi:10.1109/OCEANS-Genova.2015.7271713

Babonneau, N., Savoye, B., Cremer, M., Klein, B., 2002. Morphology and architecture of the present canyon and channel system of the Zaire deep-sea fan. Mar. Pet. Geol. 19, 445-467. doi:10.1016/S02648172(02)00009-0

Bailey, D.M., Priede, I.G., 2002. Predicting fish behaviour in response to abyssal food falls. Mar. Biol. 141, 831-840. doi:10.1007/s00227-002-0891-9

Berger, W.H., 1968. Planktonic Foraminifera: selective solution and paleoclimatic interpretation. Deep Sea Res. Oceanogr. Abstr. 15, 31-43. doi:10.1016/0011-7471(68)90027-2

Bergquist, D.C., Andras, J.P., McNelis, T., Howlett, S., Van Horn, M.J., Fisher, C.R., 2003. Succession in Gulf of Mexico Cold Seep Vestimentiferan Aggregations: The Importance of Spatial Variability. Mar. Ecol. 24, 31-44. doi:10.1046/j.1439-0485.2003.03800.x 
Bernardino, A.F., Smith, C.R., Baco, A., Altamira, I., Sumida, P.Y.G., 2010. Macrofaunal succession in sediments around kelp and wood falls in the deep NE Pacific and community overlap with other reducing habitats. Deep Sea Res. Part Oceanogr. Res. Pap. 57, 708-723. doi:10.1016/j.dsr.2010.03.004

Bessette, S., 2016. Identification des communautés microbiennes des lobes terminaux du système turbiditique du Congo [WWW Document]. http://www.theses.fr. URL http://www.theses.fr/s148758 (accessed 9.9.16).

Biscoito, M., Segonzac, M., Almeida, A., Desbruyeres, D., Geistdoerfer, P., Turnipseed, M., Van Dover, C., 2002. Fishes from the hydrothermal vents and cold seeps-An update. CBM-Cah. Biol. Mar. 43, 359-362.

Bonnel, C., 2005. Mise en place des lobes distaux dans les systèmes turbiditiques actuels : analyse comparée des systèmes du Zaïre, Var, et Rhône. Bordeaux 1.

Bright, M., Lallier, F., 2010. The biology of vestimentiferan tubeworms. Oceanogr. Mar. Biol. Annu. Rev. 48, 213-266.

Charlou, J.L., Donval, J.P., Fouquet, Y., Ondreas, H., Knoery, J., Cochonat, P., Levaché, D., Poirier, Y., JeanBaptiste, P., Fourré, E., Chazallon, B., 2004. Physical and chemical characterization of gas hydrates and associated methane plumes in the Congo-Angola Basin. Chem. Geol., Geomicrobiology and Biogeochemistry of Gas Hydrates and Hydrocarbon Seeps 205, 405-425.

doi:10.1016/j.chemgeo.2003.12.033

Chough, S., Hesse, R., 1976. Submarine meandering thalweg and turbidity, currents flowing for 4,000 km in the, Northwest Atlantic Mid-Ocean Channel, Labrador Sea. Geology 4, 529. doi:10.1130/00917613(1976)4<529:SMTATC>2.0.CO;2

Cordes, E.E., Hourdez, S., Predmore, B.L., Redding, M.L., Fisher, C.R., 2005. Succession of hydrocarbon seep communities associated with the long-lived foundation species Lamellibrachia luymesi. Mar. Ecol. Prog. Ser. 305, 17-29.

Decker, C., 2011. Diversité, écologie et adaptation des bivalves Vesicomyidae associés aux environnements réducteurs profonds des marges continentales. Brest.

Decker, C., Morineaux, M., Van Gaever, S., Caprais, J.-C., Lichtschlag, A., Gauthier, O., Andersen, A.C., Olu, K., 2012. Habitat heterogeneity influences cold-seep macrofaunal communities within and among seeps along the Norwegian margin. Part 1: macrofaunal community structure. Mar. Ecol. 33, 205-230. doi:10.1111/j.1439-0485.2011.00503.x

Decker, C., Zorn, N., Le Bruchec, J., Caprais, J.C., Potier, N., Leize-Wagner, E., Lallier, F., Olu, K., Andersen, A.C., subm., this issue. Can hemoglobin characteristics of vesicomyid clam species influence their distribution in deep-sea sulfide-rich sediments? Deep Sea Res. Part II Top. Stud. Oceanogr.

Dennielou, B., Droz, L., Jacq, C., Babonneau, N., Picot, M., Le Saout, J., Rabouille, C., Olu, this issue. Channelization and mass wasting processes at the distal lobes of the Congo deep-sea fan. Deep Sea Res. Part II Top. Stud. Oceanogr.

Dietz, R.S., 1953. Possible deep-sea turbidity-current channels in the Indian Ocean. GSA Bull. 64, 375378. doi:10.1130/0016-7606(1953)64[375:PDTCIT]2.0.CO;2 
Dill, R.F., Dietz, R.S., Stewart, H., 1954. Deep-sea channels and delta of the Monterey submarine canyon. Geol. Soc. Am. Bull. 65, 191-194. doi:10.1130/0016-7606(1954)65[191:DCADOT]2.0.CO;2

Droz, L., Marsset, T., Ondras, H., Lopez, M., Savoye, B., Spy-Anderson, F.-L., 2003. Architecture of an active mud-rich turbidite system: The Zaire Fan (Congo-Angola margin southeast Atlantic): Results from ZaAngo 1 and 2 cruises. AAPG Bull. 87, 1145-1168.

Droz, L., Rigaut, F., Cochonat, P., Tofani, R., 1996. Morphology and recent evolution of the Zaire turbidite system (Gulf of Guinea). Geol. Soc. Am. Bull. 108, 253-269. doi:10.1130/0016-

7606(1996)108<0253:MAREOT>2.3.CO;2

Duineveld, G.C., Lavaleye, M.S., Bergman, M.J., De Stigter, H., Mienis, F., 2007. Trophic structure of a cold-water coral mound community (Rockall Bank, NE Atlantic) in relation to the near-bottom particle supply and current regime. Bull. Mar. Sci. 81, 449-467.

Duros, P., Fontanier, C., Metzger, E., Pusceddu, A., Cesbron, F., de Stigter, H.C., Bianchelli, S., Danovaro, R., Jorissen, F.J., 2011. Live (stained) benthic foraminifera in the Whittard Canyon, Celtic margin (NE Atlantic). Deep Sea Res. Part Oceanogr. Res. Pap. 58, 128-146. doi:10.1016/j.dsr.2010.11.008

Embley, R.W., Eittreim, S.L., McHugh, C.H., Normark, W.R., Rau, G.H., Hecker, B., DeBevoise, A.E., Greene, H.G., Ryan, W.B.F., Harrold, C., Baxter, C., 1990. Geological setting of chemosynthetic communities in the Monteray Fan Valley system. Deep Sea Res. 37, 1651-1667.

Fischer, D., Sahling, H., Nöthen, K., Bohrmann, G., Zabel, M., Kasten, S., 2012. Interaction between hydrocarbon seepage, chemosynthetic communities, and bottom water redox at cold seeps of the Makran accretionary prism: insights from habitat-specific pore water sampling and modeling. Biogeosciences 9, 2013-2031. doi:10.5194/bg-9-2013-2012

Fisher, C.R., Cordes, E.E., Roberts, H.H., Bernard, B., 2007. Cold seeps and associated communities. Oceanography 20, 118.

Gay, A., Lopez, M., Cochonat, P., Sultan, N., Cauquil, E., Brigaud, F., 2003. Sinuous pockmark belt as indicator of a shallow buried turbiditic channel on the lower slope of the Congo basin, West African margin. Geol. Soc. Lond. Spec. Publ. 216, 173-189. doi:10.1144/GSL.SP.2003.216.01.12

Genin, A., Dayton, P.K., Lonsdale, P.F., Spiess, F.N., 1986. Corals on seamount peaks provide evidence of current acceleration over deep-sea topography. Nature 322, 59-61. doi:10.1038/322059a0

Gooday, A., Levin, L., Thomas, C., Hecker, B., 1992. The distribution and ecology of Bathysiphon filiformis Sars and B. major de Folin (Protista, Foraminiferida) on the continental slope off North Carolina. J. Foraminifer. Res. 22, 129-146.

Guillon, E., Menot, L., Decker, C., Krylova, E.M., Olu, K., 2017. The vesicomyid bivalve habitat at cold seeps supports heterogeneous and 1 dynamic macrofaunal assemblages. Deep Sea Res. Part Oceanogr. Res. Pap. 120, 1-13.

Heezen, B.C., Menzies, R.J., Schneider, E.D., Ewing, W.M., Granelli, N.C.L., 1964. Congo submarine canyon. AAPG Bull. 48, 1126-1149. 
Hess, S., Jorissen, F.J., 2009. Distribution patterns of living benthic foraminifera from Cap Breton canyon, Bay of Biscay: Faunal response to sediment instability. Deep Sea Res. Part Oceanogr. Res. Pap. 56, 15551578. doi:10.1016/j.dsr.2009.04.003

Hess, S., Jorissen, F.J., Venet, V., Abu-Zied, R., 2005. Benthic Foraminiferal Recovery After Recent Turbidite Deposition in Cap Breton Canyon, Bay of Biscay. J. Foraminifer. Res. 35, 114-129.

doi:10.2113/35.2.114

Higgs, N.D., Gates, A.R., Jones, D.O.B., 2014. Fish food in the deep sea: revisiting the role of large foodfalls. PLoS ONE 9. doi:10.1371/journal.pone.0096016

Janßen, F., Treude, T., Witte, U., 2000. Scavenger assemblages under differing trophic conditions: a case study in the deep Arabian Sea. Deep Sea Res. Part II Top. Stud. Oceanogr. 47, 2999-3026.

doi:10.1016/S0967-0645(00)00056-4

Khripounoff, A., Vangriesheim, A., Babonneau, N., Crassous, P., Dennielou, B., Savoye, B., 2003. Direct observation of intense turbidity current activity in the Zaire submarine valley at $4000 \mathrm{~m}$ water depth. Mar. Geol. 194, 151-158. doi:10.1016/S0025-3227(02)00677-1

Koho, K.A., García, R., de Stigter, H.C., Epping, E., Koning, E., Kouwenhoven, T.J., van der Zwaan, G.J., 2008. Sedimentary labile organic carbon and pore water redox control on species distribution of benthic foraminifera: A case study from Lisbon-Setúbal Canyon (southern Portugal). Prog. Oceanogr. 79, 55-82. doi:10.1016/j.pocean.2008.07.004

Krylova, E.M., Sahling, H., 2010. Vesicomyidae (bivalvia): current taxonomy and distribution. PLoS ONE 5, e9957. doi:10.1371/journal.pone.0009957

Krylova, E.M., von Cosel, R., 2011. A new genus of large Vesicomyidae (Mollusca, Bivalvia, Vesicomyidae, Pliocardiinae) from the Congo margin, with the first record of the subfamily Pliocardiinae in the Bay of Biscay (northeastern Atlantic). Zoosystema 33, 83-99. doi:10.5252/z2011n1a4

Marcon, Y., Sahling, H., Allais, A.-G., Bohrmann, G., Olu, K., 2014. Distribution and temporal variation of mega-fauna at the Regab pockmark (Northern Congo Fan), based on a comparison of videomosaics and geographic information systems analyses. Mar. Ecol. 35, 77-95. doi:10.1111/maec.12056

Mayer, L.A., Shor, A.N., Clarke, J.H., Piper, D.J.W., 1988. Dense biological communities at $3850 \mathrm{~m}$ on the Laurentian Fan and their relationship to the deposits of the 1929 Grand banks earthquake. Deep Sea Res. 35, 1235-1246.

Meiburg, E., Kneller, B., 2010. Turbidity currents and their deposits. Annu. Rev. Fluid Mech. 42, 135-156. doi:10.1146/annurev-fluid-121108-145618

Menard, H.W.J., 1955. Deep-sea channels, topography, and sedimentation. AAPG Bull. 39, 236-255.

Milliman, J.D., Meade, R.H., 1983. World-wide delivery of river sediment to the oceans. J. Geol. 91, 1-21.

Mulder, T., 2011. Gravity processes and deposits on continental slope, rise and abyssal plains, in: Developments in Sedimentology. Elsevier, pp. 25-148.

Olu, K., 2011. WACS cruise, R/V Pourquoi Pas? 
Olu, K., Caprais, J.C., Galéron, J., Causse, R., von Cosel, R., Budzinski, H., Ménach, K.L., Roux, C.L., Levaché, D., Khripounoff, A., Sibuet, M., 2009. Influence of seep emission on the non-symbiont-bearing fauna and vagrant species at an active giant pockmark in the Gulf of Guinea (Congo-Angola margin). Deep Sea Res. Part II Top. Stud. Oceanogr. 56, 2380-2393. doi:10.1016/j.dsr2.2009.04.017

Olu-Le Roy, K., Caprais, J.-C., Fifis, A., Fabri, M.-C., Galéron, J., Budzinsky, H., Le Ménach, K., Khripounoff, A., Ondréas, H., Sibuet, M., 2007. Cold-seep assemblages on a giant pockmark off West Africa: spatial patterns and environmental control. Mar. Ecol. 28, 115-130. doi:10.1111/j.1439-0485.2006.00145.x

Ondréas, H., Olu, K., Fouquet, Y., Charlou, J.L., Gay, A., Dennielou, B., Donval, J.P., Fifis, A., Nadalig, T., Cochonat, P., Cauquil, E., Bourillet, J.F., Moigne, M.L., Sibuet, M., 2005. ROV study of a giant pockmark on the Gabon continental margin. Geo-Mar. Lett. 25, 281-292. doi:10.1007/s00367-005-0213-6

Pastor, L., Toffin, L., Caprais, J.C., Bessette, S., Lesongeur, F., Brandily, C., Godfroy, A., Olu, subm., this issue. Evidence for AOM in symbiotic bivalves habitats from the Congo deep-sea fan lobes. Deep Sea Res. Part II Top. Stud. Oceanogr.

Paull, C.K., Schlining, B., Ussler III, W., Lundste, E., Barry, J.P., Caress, D.W., Johnson, J.E., McGann, M., 2010. Submarine mass transport within Monterey Canyon: Benthic disturbance controls on the distribution of chemosynthetic biological communities, in: Submarine Mass Movements and Their Consequences. Springer, pp. 229-246.

Picot, M., 2015. Cycles sédimentaires dans le système turbiditique du Congo : nature et origine. Université de Bretagne Occidentale, Brest.

Pruski, A.M., Decker, C., Stetten, E., Vétion, G., Martinez, P., Charlier, K., Senyarich, C., Olu, accepted, this issue. Energy transfer in the Congo turbiditic system: from terrestrially-derived organic matter to chemosynthetic food webs. Deep Sea Res. Part II Top. Stud. Oceanogr.

Rabouille, C., 2011. CONGOLOBE Cruise, R/V Pourquoi Pas?

Rabouille, C., Caprais, J.-C., Lansard, B., Crassous, P., Dedieu, K., Reyss, J.L., Khripounoff, A., 2009. Organic matter budget in the Southeast Atlantic continental margin close to the Congo Canyon: In situ measurements of sediment oxygen consumption. Deep Sea Res. Part II Top. Stud. Oceanogr. 56, 22232238. doi:10.1016/j.dsr2.2009.04.005

Rabouille, C., Olu, K., Baudin, F., Khripounoff, A., Dennielou, B., Arnaud-Haond, S., Babonneau, N., Bayle, C., Beckler, J., Bessette, S., Bombled, B., Bourgeois, S., Brandily, C., Caprais, J.C., Cathalot, C., Charlier, K., Corvaisier, R., Croguennec, C., Cruaud, P., Decker, C., Droz, L., Gayet, N., Godfroy, A., Hourdez, S., Le Bruchec, J., Le Saout, J., Lesaout, M., Lesongeur, F., Martinez, P., Mejanelle, L., Michalopoulos, P., Mouchel, O., Noel, P., Pastor, L., Picot, M., Pignet, P., Pozzato, L., Pruski, A.M., Rabiller, M., Raimonet, M., Ragueneau, O., Reyss, J.L., Rodier, P., Ruesch, B., Ruffine, L., Savignac, F., Senyarich, C., Schnyder, J., Sen, A., Stetten, E., Sun, M.Y., Taillefert, M., Teixeira, S., Tisnerat-Laborde, N., Toffin, L., Tourolle, J., Toussaint, F., Vétion, G., Jouanneau, J.M., Bez, M., 2016. The Congolobe project, a multidisciplinary study of Congo deep-sea fan lobe complex: Overview of methods, strategies, observations and sampling. Deep Sea Res. Part II Top. Stud. Oceanogr. doi:10.1016/j.dsr2.2016.05.006

Rex, M.A., 1981. Community structure in the deep-sea benthos. Annu. Rev. Ecol. Syst. 12, 331-353. doi:10.1146/annurev.es.12.110181.001555 
Sanders, H.L., Hessler, R.R., 1969. Ecology of the deep-sea benthos. Science 163, 1419-1424. doi:10.2307/1726124

Savoye, B., Babonneau, N., Dennielou, B., Bez, M., 2009. Geological overview of the Angola-Congo margin, the Congo deep-sea fan and its submarine valleys. Deep Sea Res. Part II Top. Stud. Oceanogr. 56, 2169-2182. doi:10.1016/j.dsr2.2009.04.001

Savoye, B., Ondréas, H., 2000. ZAINGOROV cruise, R/V L'Atalante.

Sibuet, M., Roy, K.O.-L., 2002. Cold Seep Communities on Continental Margins: Structure and Quantitative Distribution Relative to Geological and Fluid Venting Patterns, in: Wefer, P.D.G., Billett, D.D., Hebbeln, D.D., Jørgensen, P.D.B.B., Schlüter, P.D.M., Weering, D.T.C.E. van (Eds.), Ocean Margin Systems. Springer Berlin Heidelberg, pp. 235-251. doi:10.1007/978-3-662-05127-6_15

Simeoni, P., Sarrazin, J., Nouze, H., Sarradin, P.-M., Ondreas, H., Scalabrin, C., Sinquin, J.-M., 2007. Victor 6000: New high resolution tools for deep sea research. « Module de Mesures en Route ». Oceans 2007 Eur. Vols 1-3 133-138.

Smith, C.R., Baco, A.R., 2003. Ecology of whale falls at the deep-sea floor. Oceanogr. Mar. Biol. 41, 311354.

Smith, P.A., 1942. Review of submarine topography off the California coast: canyons and tectonic interpretation. Geogr. Rev. 32, 691-693. doi:10.2307/210015

Southward, E.C., Schulze, A., Gardiner, S.L., 2005. Pogonophora (Annelida): form and function. Hydrobiologia 535/536, 227-251.

Stetten, E., Baudin, F., Reyss, J.-L., Martinez, P., Charlier, K., Schnyder, J., Rabouille, C., Dennielou, B., Coston-Guarini, J., Pruski, A.M., 2015. Organic matter characterization and distribution in sediments of the terminal lobes of the Congo deep-sea fan: Evidence for the direct influence of the Congo River. Mar. Geol. 369, 182-195. doi:10.1016/j.margeo.2015.08.020

Taillefert, M., Beckler, J., Cathalot, C., Panagiotis, M., Corvaisier, R., Kiriazis, N., Caprais, J.-C., Pastor, L., Rabouille, C., subm., this issue. Early diagenesis in the sediments of the Congo deep-sea fan dominated by massive terrigenous deposits: Part II - Iron-sulfur coupling. Deep Sea Res. Part II Top. Stud. Oceanogr.

Teixeira, S., Olu, K., Decker, C., Cunha, R.L., Fuchs, S., Hourdez, S., Serrão, E.A., Arnaud-Haond, S., 2013. High connectivity across the fragmented chemosynthetic ecosystems of the deep Atlantic Equatorial Belt: efficient dispersal mechanisms or questionable endemism? Mol. Ecol. 22, 4663-4680.

doi:10.1111/mec.12419

Thunell, R.C., 1982. Carbonate dissolution and abyssal hydrography in the Atlantic Ocean. Mar. Geol. 47, 165-180. doi:10.1016/0025-3227(82)90067-6

Van Dover, C.L., 2000. The ecology of deep-sea hydrothermal vents, 1st ed. Princeton University Press.

Vangriesheim, A., Khripounoff, A., Crassous, P., 2009. Turbidity events observed in situ along the Congo submarine channel. Deep Sea Res. Part II Top. Stud. Oceanogr., Deep-Sea Benthic Ecosystems of the Equatorial African Margin: The Multidisciplinary BIOZAIRE ProgramA Contribution to Census of Marine Life 56, 2208-2222. doi:10.1016/j.dsr2.2009.04.004 
von Cosel, R., Olu, K., 2009. Large Vesicomyidae (Mollusca: Bivalvia) from cold seeps in the Gulf of Guinea off the coasts of Gabon, Congo and northern Angola. Deep Sea Res. Part II Top. Stud. Oceanogr., Deep-Sea Benthic Ecosystems of the Equatorial African Margin: The Multidisciplinary BIOZAIRE Program A Contribution to Census of Marine Life 56, 2350-2379. doi:10.1016/j.dsr2.2009.04.016

Witte, U., 1999. Consumption of large carcasses by scavenger assemblages in the deep Arabian Sea: observations by baited camera. Mar. Ecol. Prog. Ser. 183, 139-147. doi:10.3354/meps183139

Figure 1: The Congo fan deep lobe complex and the location of the study area. The three sites targeted for this study (Sites A, F and C) are outlined as boxes. Numbers represent the various lobes.

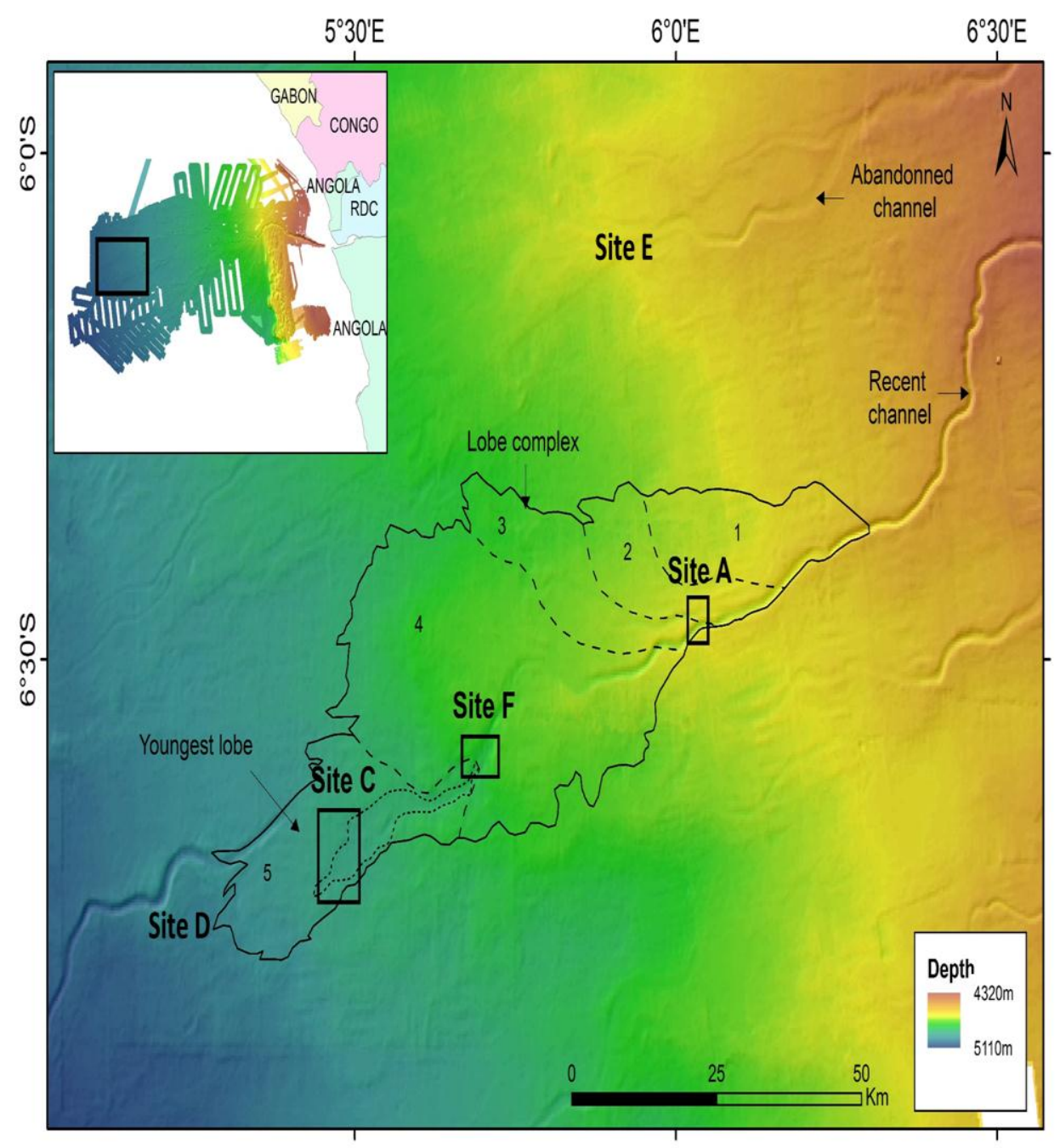

Figure 2: Example of a zoomed in portion of a mosaic. This mosaic portion consists of five individual images, one of which is shown on the right. 

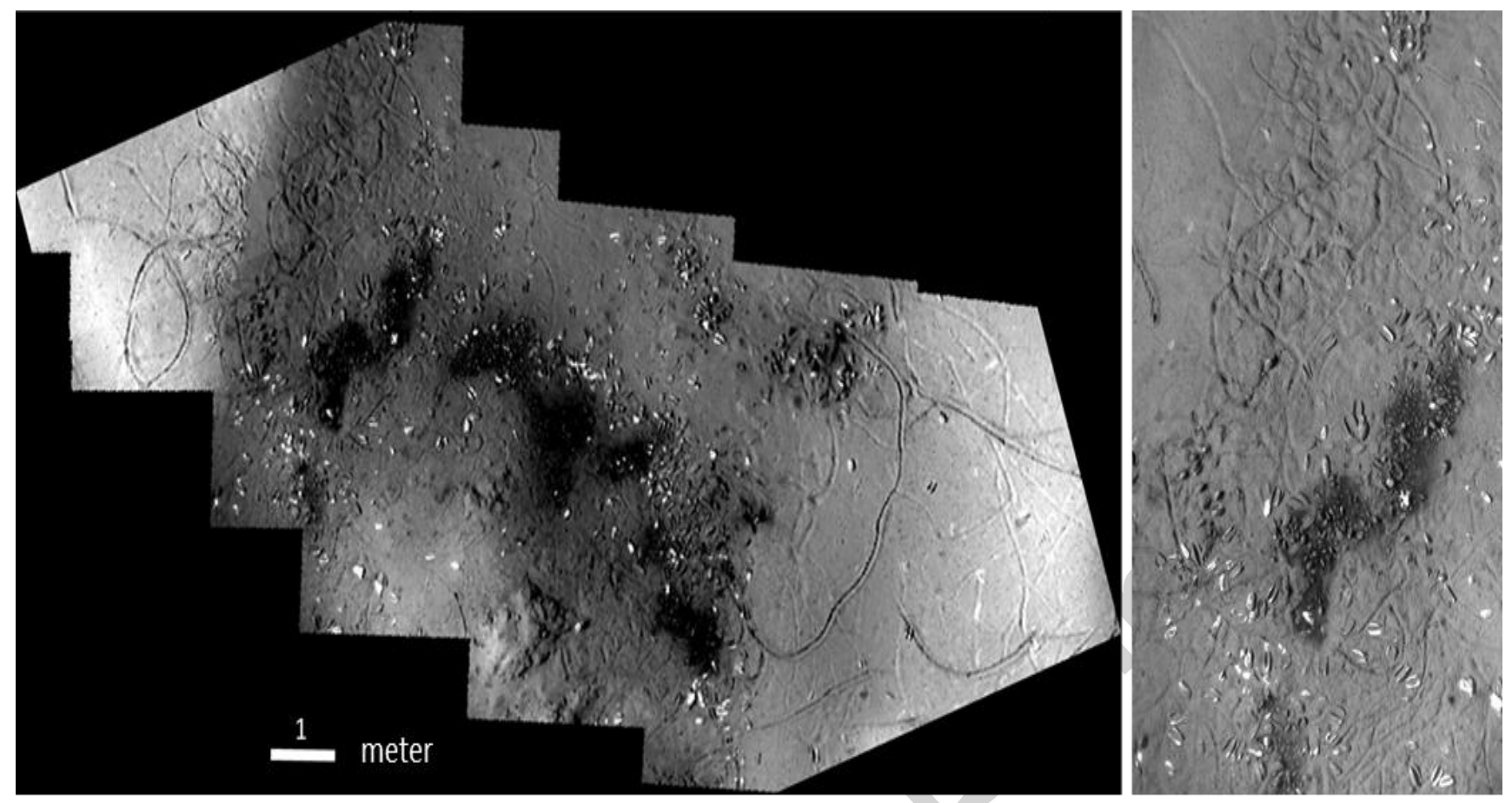

Figure 3: The various substrate/habitat and aggregation types that were outlined in the georeferenced mosaics: reduced black sediment (A), dense vesicomyid clams (B), foraminifers (C), dense clam shells (D), patchy black sediment $(E)$, patchy white sediment $(F)$, mixed black and white sediment $(G)$, and white bacterial mats $(\mathrm{H})$. Scale bars are $0.5 \mathrm{~m}$. 

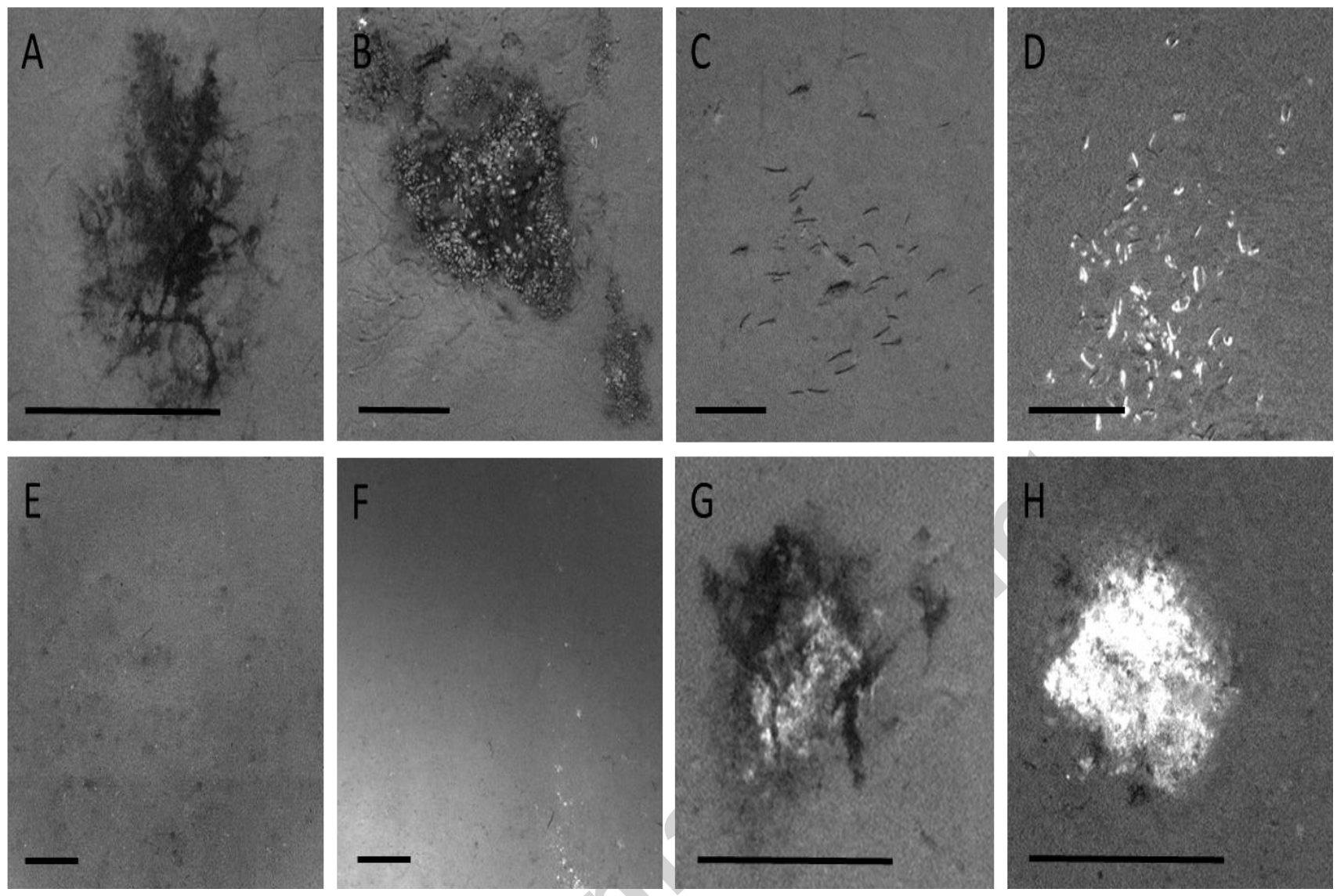

Figure 4: Site A. Bathymetry of the area, with mosaics (grey). High-resolution, ROV obtained bathymetry is overlain on the lower resolution, ship acquired bathymetry (scale refers to high-resolution bathymetry). Vesicomyid aggregations, foraminifer aggregations, clam shells and black sediment are displayed as digitized polygons of various colors. Vesico Bay is outlined in black on the right is a close up of the bathymetric map of Vesico Bay and a still image obtained from video transects of the area. 

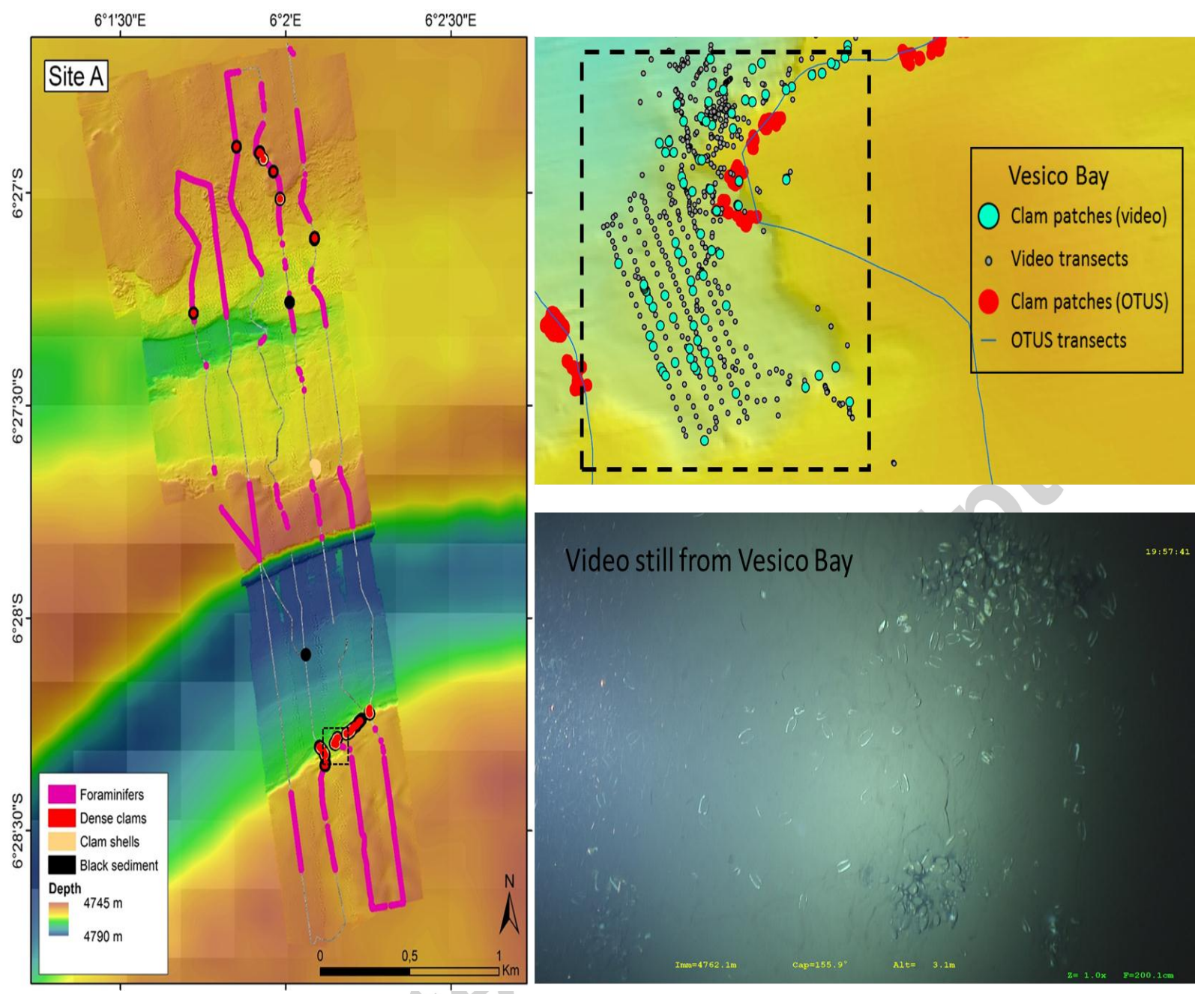

Figure 5: Site F. Bathymetry of the area, with mosaics (grey). High-resolution, ROV obtained bathymetry is overlain on the lower resolution, ship acquired bathymetry (scale refers to high-resolution bathymetry). Vesicomyid aggregations, foraminifer aggregations, clam shells and the different sediment 
types are displayed as digitized polygons of various colors.

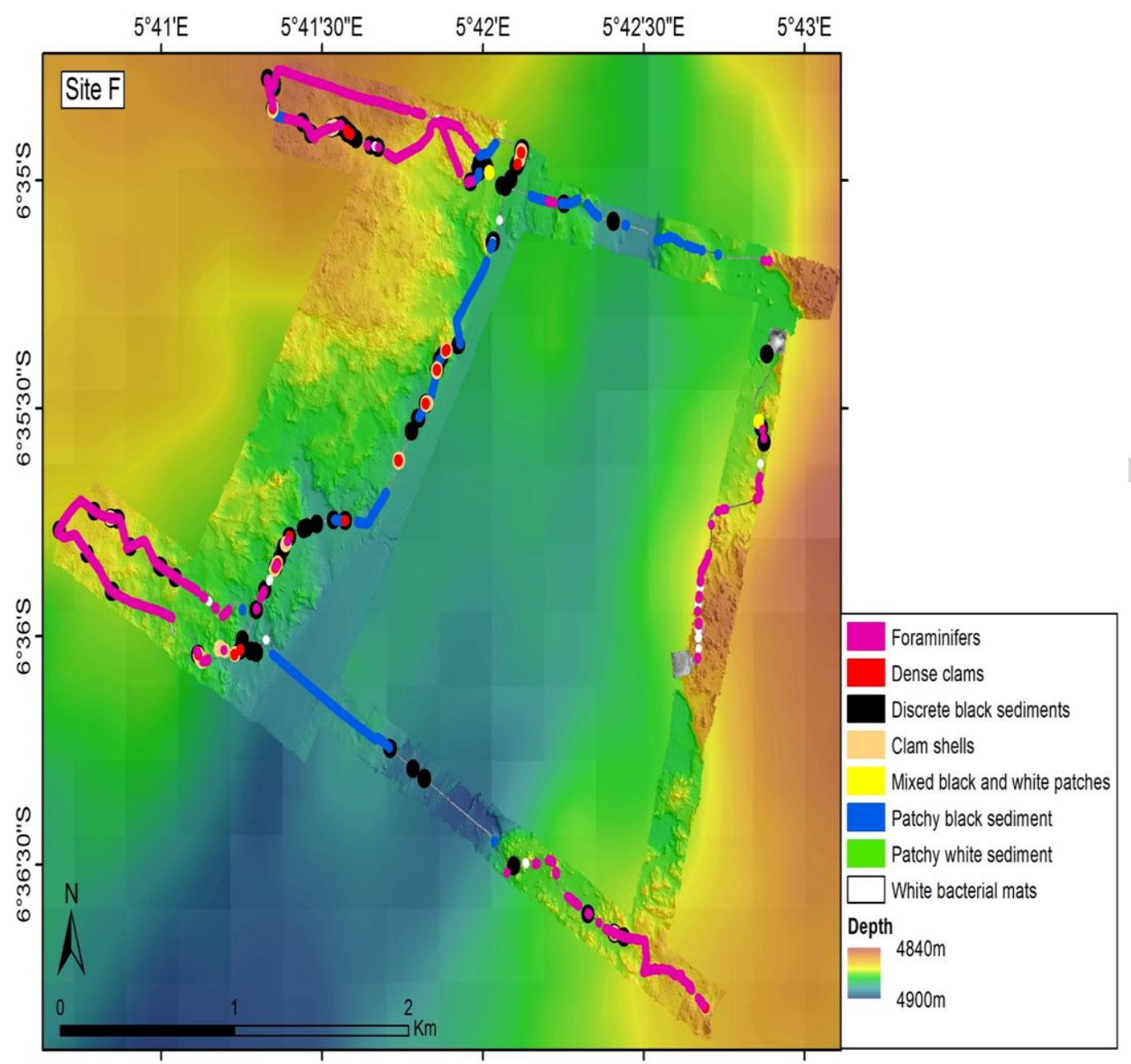

Figure 6: Site C. Bathymetry of the area, with mosaics (grey). High-resolution, ROV obtained bathymetry is overlain on the lower resolution, ship acquired bathymetry (scale refers to high-resolution bathymetry. The visible difference between the two bathymetry maps in the top portion is due to offsets between the two datasets, that could not be corrected. Vesicomyid aggregations, foraminifer 
aggregations, clam shells and the different sediment types are displayed as digitized polygons of various

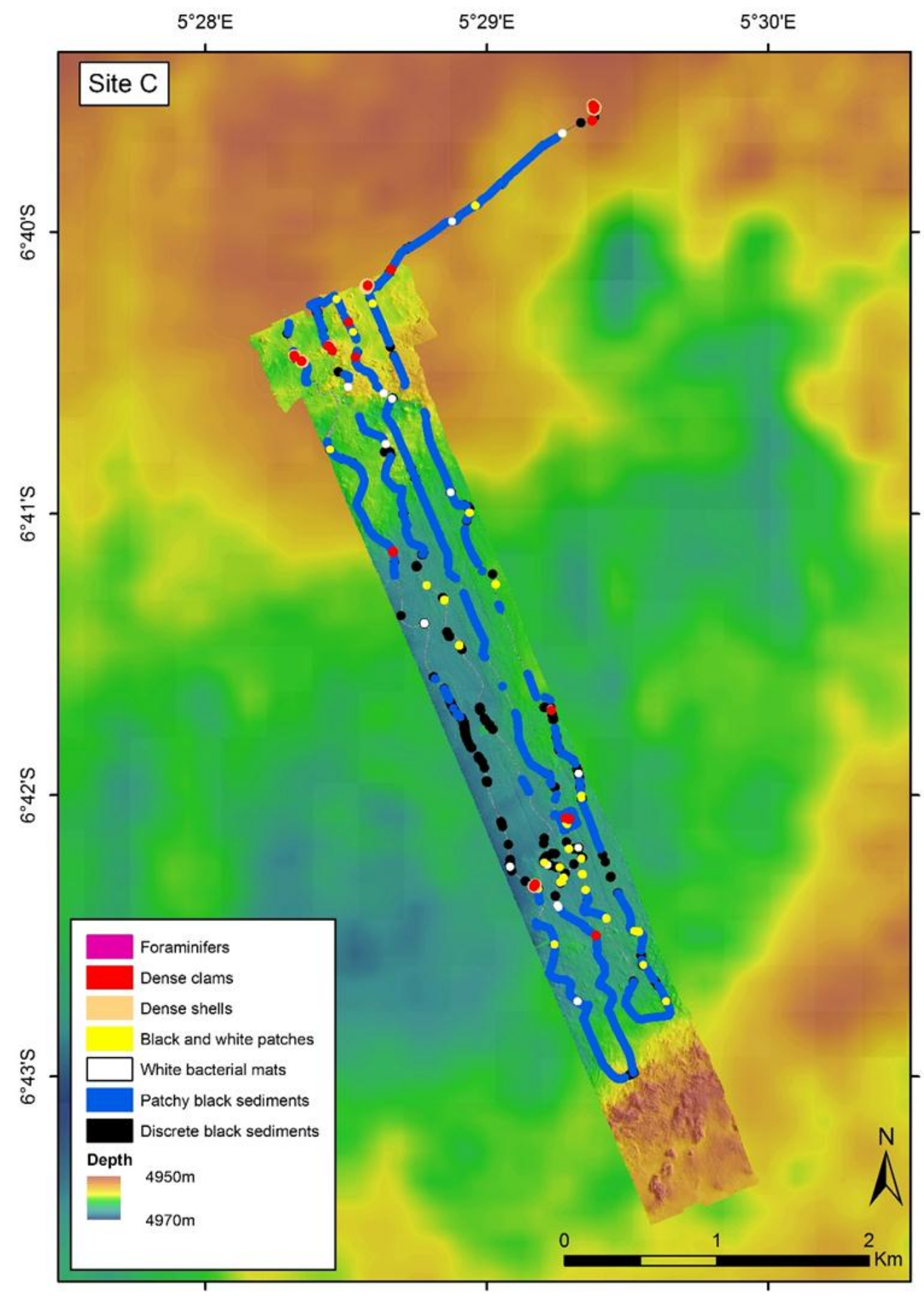

colors.

Figure 7: Video stills showing a sideways view of selected vesicomyid aggregations, where the relief of features is more visible than in the downward facing OTUS images. A: vesicomyids on a slope in the 
southern flank of the channel at site A. B: vesicomyids on an escarpment along the southern side of the channel at site A. C: vesicomyids on the flat top of a blocky hill at the marker W11, within site A.
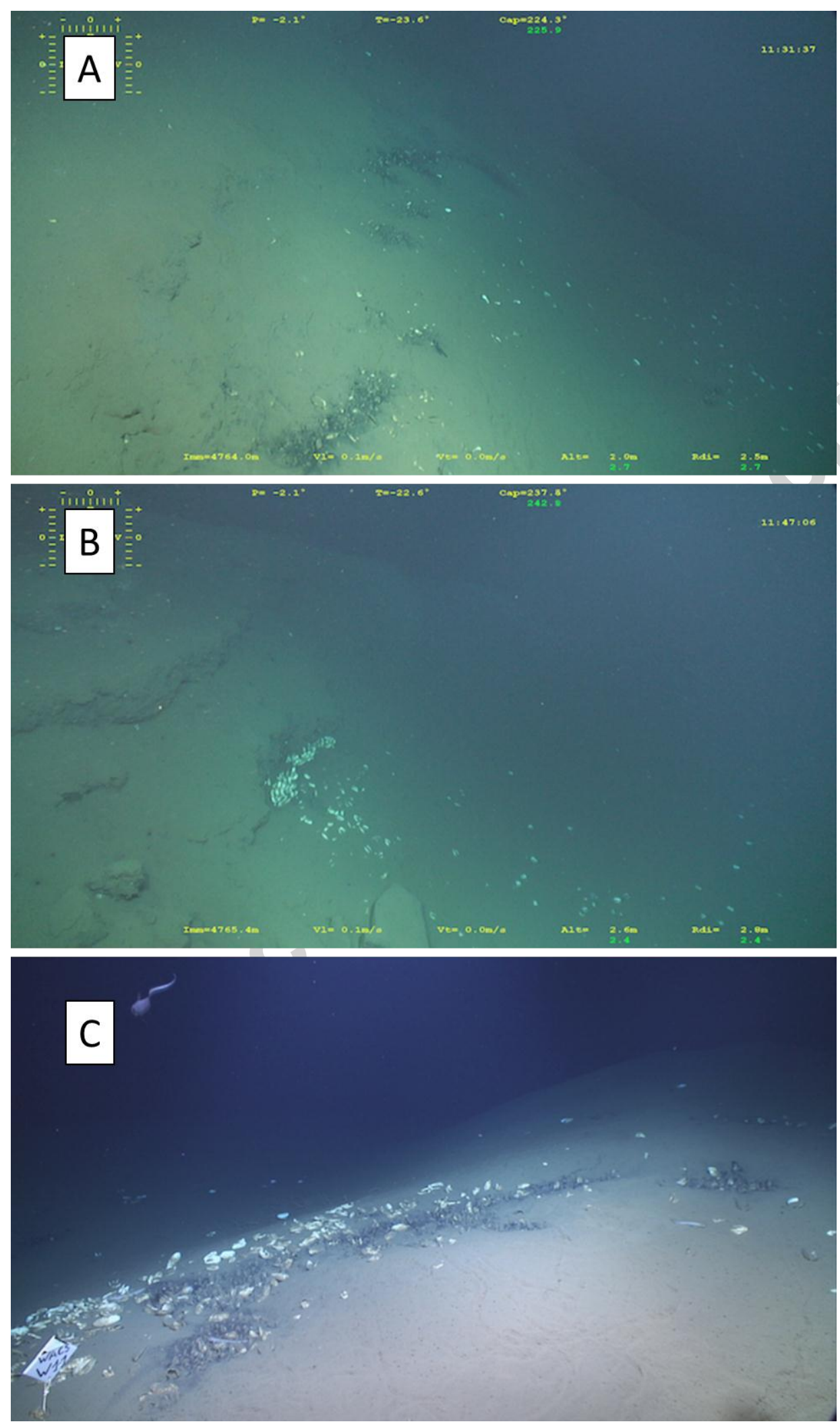
Figure 8: Site A with all the point fauna (animals digitized as single points for each individual) displayed. The mosaics (grey) are overlain on the bathymetry (lower resolution, shipboard bathymetry for the background, high-resolution, ROV acquired for the site itself. Scale refers to the high-resolution 
bathymetry).

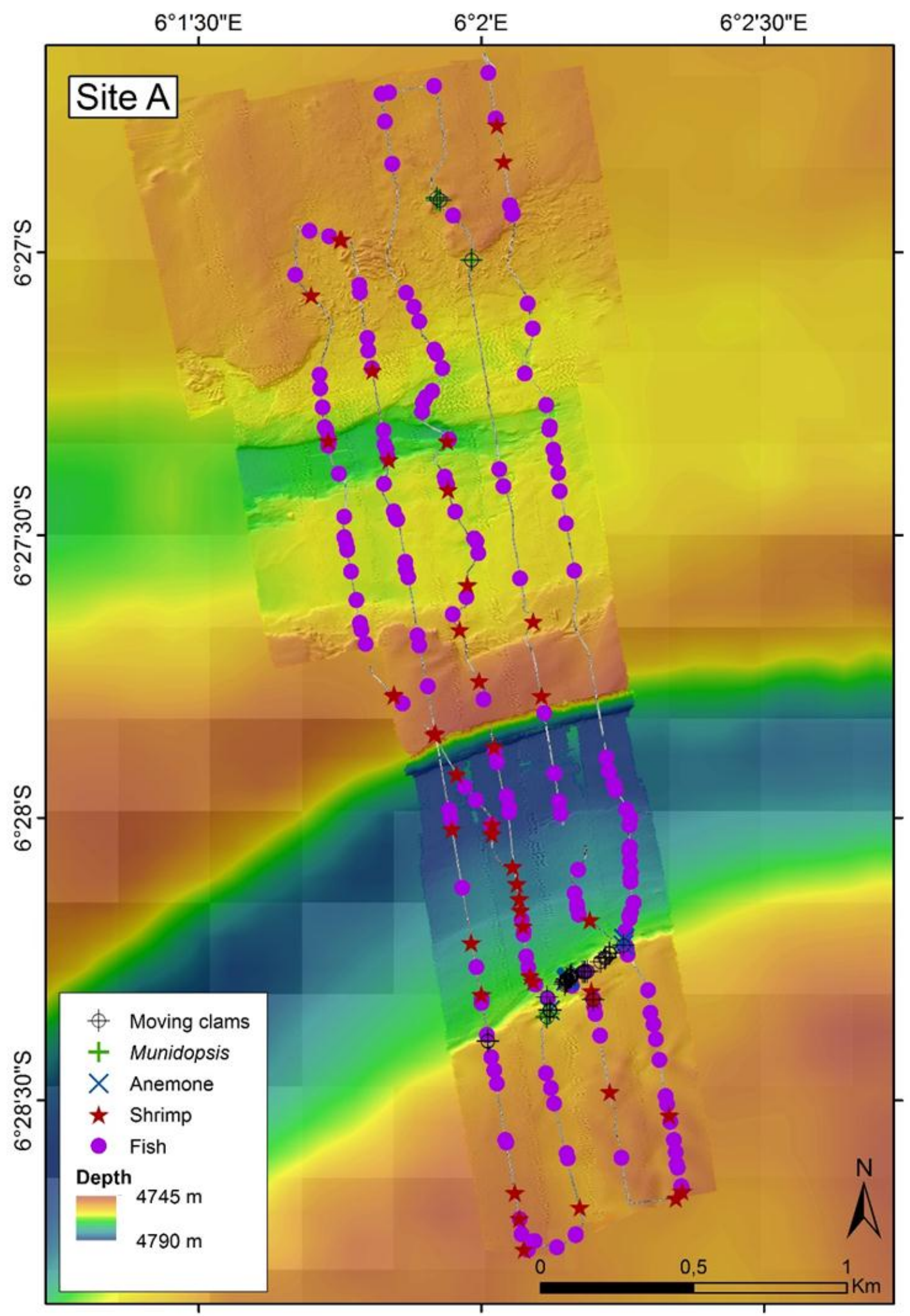


Figure 9: Site $\mathrm{F}$ with all the point fauna (animals digitized as single points for each individual) displayed. The mosaics (grey) are overlain on the bathymetry (lower resolution, shipboard bathymetry for the background, high-resolution, ROV acquired for the site itself. Scale refers to the high-resolution bathymetry).

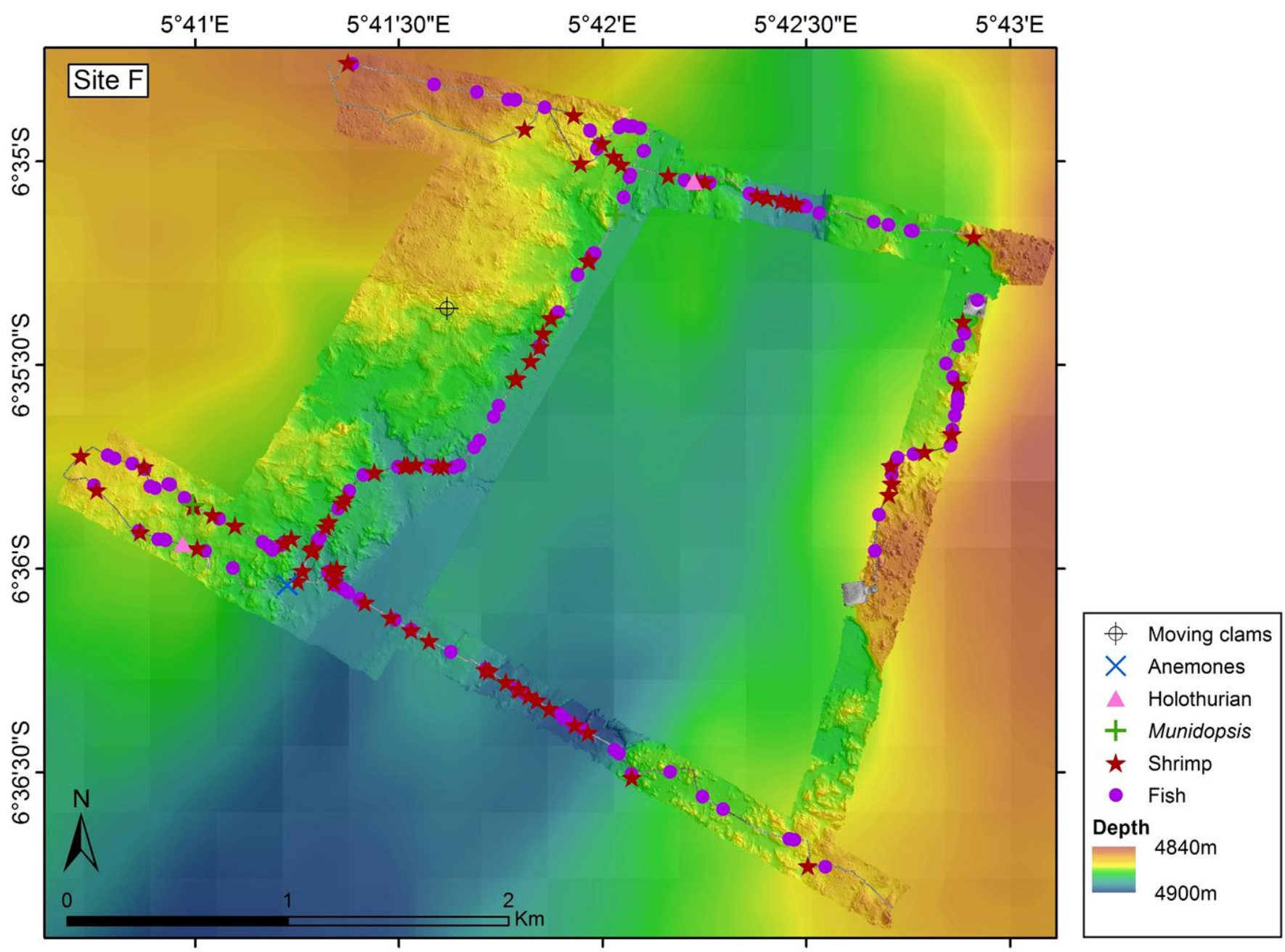


Figure 10: Site $\mathrm{C}$ with all the point fauna (animals digitized as single points for each individual) displayed. The mosaics (grey) are overlain on the bathymetry map (lower resolution, shipboard bathymetry for the background, high-resolution, ROV acquired for the site itself. Scale refers to the high-resolution bathymetry. The visible difference between the two bathymetry maps in the top portion is due to 
offsets between the two datasets, that could not be corrected).

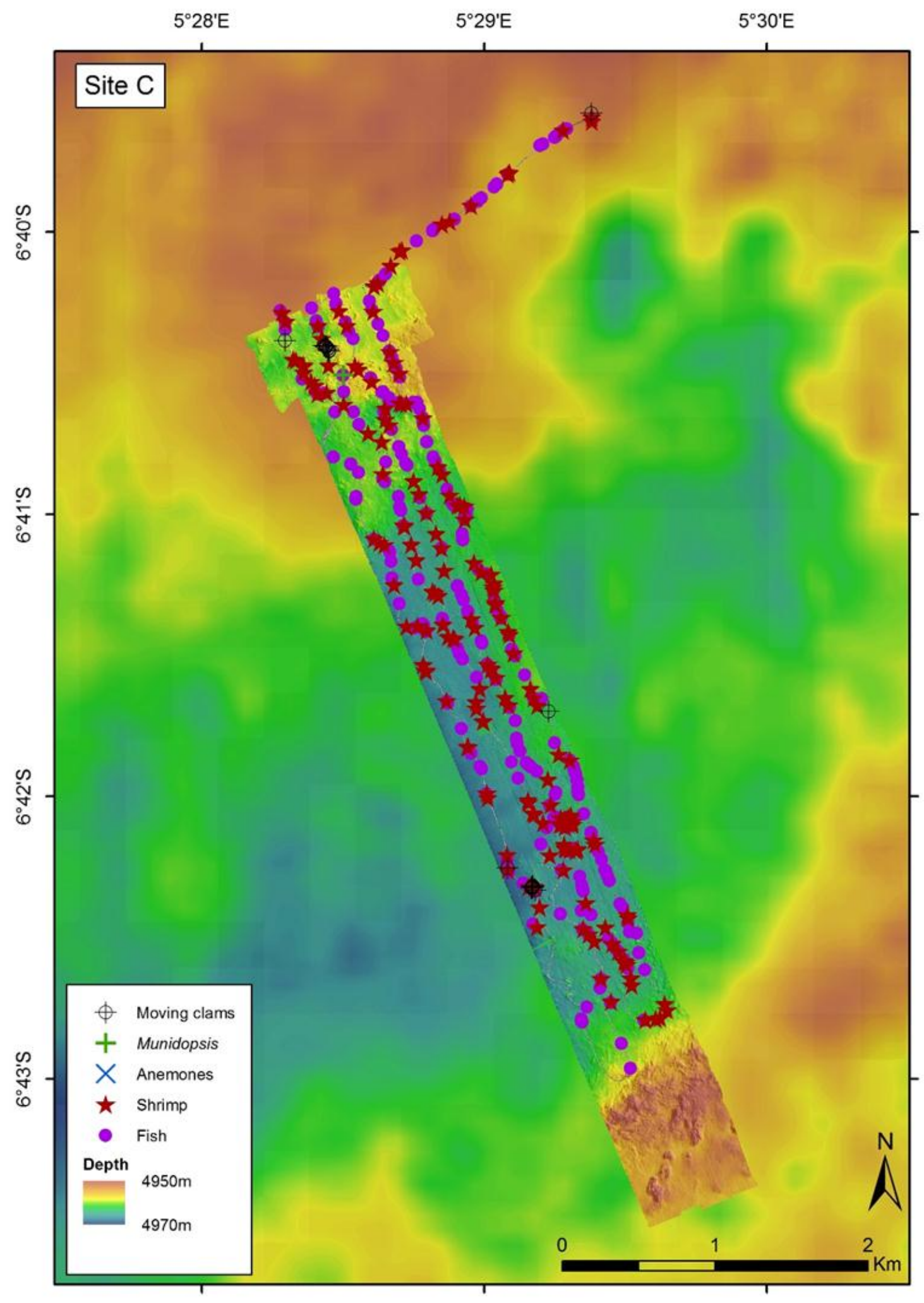


Figure 11: Schematic diagram of the Congo fan lobe complex morphology and distribution of habitats and aggregated fauna. Thick, red lines represent bathymetric sections across sites A, F and C. Grey color indicates dominantly muddy deposits on the levees and areas adjacent to the channels, yellow color indicates dominantly sandy deposits in the channels (cf detailed description of morphology and sedimentary facies in Dennielou et al., this issue). White, bacterial mats and patches of black, reduced sediment are seen throughout the system, but increase in density as one moves from A to C. High speed currents prevent colonization of forams and vesicomyid clams in the narrow parts of the channel (Sites A and F). Instead, they colonize the canyon flanks and levees, with vesicomyids on the edges and forams further away. In wider parts of the channel (Site C), vesicomyids colonize both the channel and the levees, but forams are not present, likely because of extremely high sedimentation rates. Vesicomyids form few large dense aggregations, but are patchily distributed. Vesicomyids are associated with black, reduced sediment and blocky scars, slides and slumps, whereas forams are located on smooth, flat surfaces without any visibly reduced sediment. Individual vesicomyids, outside dense aggregations are also seen, along with multiple trails in the sediment, indicating a highly mobile lifestyle.

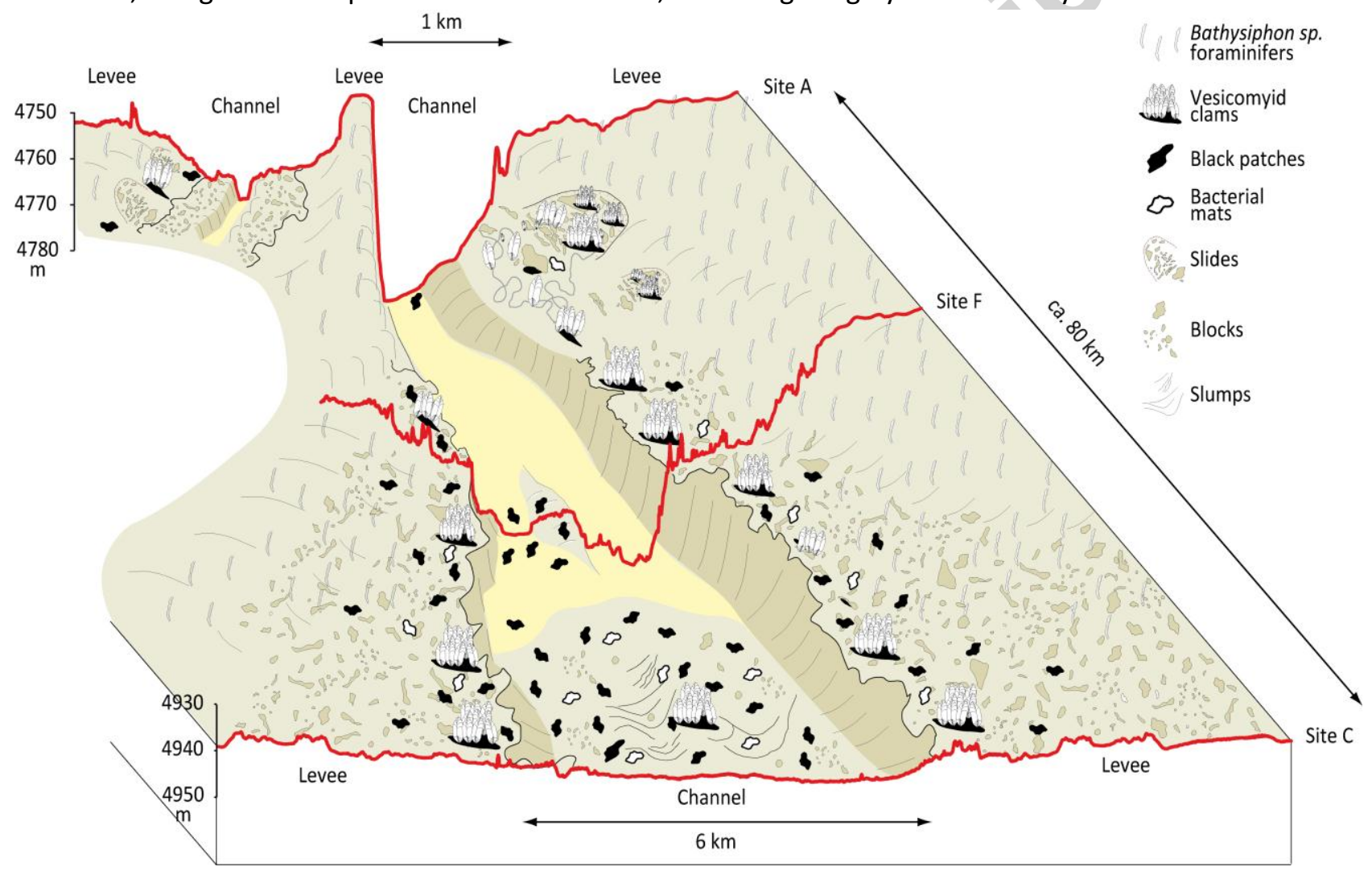

Table 1: Details of the mosaic areas at each study site and respective coverages of vesicomyid clams and discrete patches of reduced, black sediment. All area units are $\mathrm{m}^{2}$.

\begin{tabular}{|c|c|c|c|c|c|c|c|c|c|c|}
\hline Sit & $\begin{array}{l}\text { Total } \\
\text { survey } \\
\text { ed area }\end{array}$ & $\begin{array}{l}\text { Are } \\
\text { a } \\
\text { wit } \\
\text { h } \\
\text { cla }\end{array}$ & $\begin{array}{l}\text { Perce } \\
\text { nt } \\
\text { (area } \\
\text { ) } \\
\text { cover }\end{array}$ & $\begin{array}{l}\text { Num } \\
\text { ber } \\
\text { of } \\
\text { clam } \\
\text { patch }\end{array}$ & $\begin{array}{l}\text { Num } \\
\text { ber } \\
\text { of } \\
\text { black } \\
\text { patch }\end{array}$ & $\begin{array}{l}\text { Number } \\
\text { (n), } \\
\text { percent of } \\
\text { black } \\
\text { patches }\end{array}$ & $\begin{array}{l}\text { Number } \\
\text { (n), } \\
\text { percent } \\
\text { of clam } \\
\text { patches }\end{array}$ & $\begin{array}{l}\text { Mea } \\
\mathrm{n} \\
\text { clam } \\
\text { patc } \\
\mathrm{h}\end{array}$ & $\begin{array}{l}\text { Number } \\
(\mathrm{n}) \text { and } \\
\text { percent of } \\
\text { clam } \\
\text { patches < }\end{array}$ & $\begin{array}{l}\text { Number } \\
\text { (n) and } \\
\text { percent of } \\
\text { clam } \\
\text { patches < }\end{array}$ \\
\hline
\end{tabular}




\begin{tabular}{|c|c|c|c|c|c|c|c|c|c|c|}
\hline & & $\mathrm{ms}$ & $\begin{array}{l}\text { ed by } \\
\text { clams }\end{array}$ & es & es & with clams & $\begin{array}{l}\text { on black } \\
\text { sediment }\end{array}$ & size & $0.1 \mathrm{~m}^{2}$ & $0.2 \mathrm{~m}^{2}$ \\
\hline $\bar{A}$ & $\begin{array}{c}138289 \\
.98\end{array}$ & 65 & 0.05 & 231 & 186 & $\begin{array}{c}169(\mathrm{n}), \\
90.8 \%\end{array}$ & $\begin{array}{c}172(\mathrm{n}) \\
74.5 \%\end{array}$ & $\begin{array}{c}0.28 \\
22\end{array}$ & $\begin{array}{l}154(n), \\
66.67 \%\end{array}$ & $\begin{array}{l}190(n), \\
82.25 \%\end{array}$ \\
\hline $\mathrm{F}$ & $\begin{array}{c}99415 . \\
2\end{array}$ & 5.5 & 0.01 & 85 & 228 & $\begin{array}{c}48(n), \\
21 \%\end{array}$ & $\begin{array}{l}48(n) \\
56.5 \%\end{array}$ & $\begin{array}{c}0.06 \\
51\end{array}$ & $\begin{array}{c}67(n), \\
78.82 \%\end{array}$ & $\begin{array}{c}77(\mathrm{n}), \\
90.59 \%\end{array}$ \\
\hline C & $\begin{array}{c}190190 \\
.7\end{array}$ & 28 & 0.02 & 119 & 700 & $\begin{array}{c}62(n), \\
8.9 \%\end{array}$ & $\begin{array}{l}72(n) \\
60.5 \%\end{array}$ & $\begin{array}{c}0.23 \\
61\end{array}$ & $\begin{array}{c}73(n) \\
61.34 \%\end{array}$ & $\begin{array}{c}97(n), \\
81.51 \%\end{array}$ \\
\hline All & $\begin{array}{c}427895 \\
.88\end{array}$ & $\begin{array}{c}98 . \\
5\end{array}$ & 0.02 & 435 & 1114 & $\begin{array}{l}279(n) \\
25.04 \%\end{array}$ & $\begin{array}{c}292(n) \\
67.1 \%\end{array}$ & 0.19 & $\begin{array}{l}294(n), \\
67.59 \%\end{array}$ & $\begin{array}{l}364(n), \\
83.68 \%\end{array}$ \\
\hline
\end{tabular}

